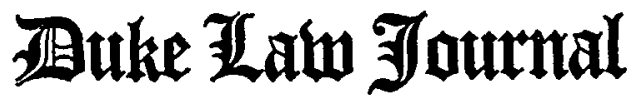

\begin{tabular}{lll}
\hline VolUMe 1973 & AUGUST & NUMBER 3 \\
\hline
\end{tabular}

\section{REQUIREMENTS AND OUTPUT CONTRACTS: QUANTITY VARIATIONS UNDER THE UCC}

\author{
JOHN C. WEISTART*
}

\section{Introduction: The Ambigutty OF the CODE}

Despite the many advantages which may attend revisions of basic commercial law such as that undertaken in the Uniform Commerical Code, there is a danger that proposal of a broad-based modification will invite commentary on many fronts and so diffuse the attention of both drafters and critics that the relative importance of a particular change may not be appreciated. Such appears to have been the case with respect to section 2-306 of the UCC dealing with requirements and output contracts. The section is a significant departure from prior uniform sales legislation which attempted no codification of the law in this area. $^{1}$ If the originality of the codification did not prompt debate, then

* Professor of Law, Duke University. A.B. 1965, Illinois Wesleyan University; J.D. 1968, Duke University.

1. Pre-Code decisions treating output and requirements contracts are discussed in 1A A. Corbin, Contracts $\$ \S 156-58$ \& 168 (1963); 3 id. $\$ 569$ (1960); 1 S. WiLliston, Contracts $\S 104 \mathrm{~A}$ (3d ed. 1957); 3 id. $\$ 421 \mathrm{~A}$ (3d ed. 1960); 2 S. Williston, SAles $\$ \S 464(a)$-(d) (1948); and Havighurst \& Berman, Requirement and Output Contracts, 27 ILL. L. Rev. 1 (1932).

HEREINAFTER THE FOLLOWING CITATIONS WILL BE USED IN THIS ARTICLE:

A. Corbin, Contracts (1960) [hereinafter cited as CoRbin];

3 R. Duesenberg \& L. King, Sales and Bulr Sales (1968) [hereinafter cited as DUESENBERg \& KING];

Havighurst \& Berman, Requirement and Output Contracts, 27 ILL. L. Rev. 1 (1932) [hereinafter cited as Havighurst \& Berman];

Note, The Construction of Requirements Contracts and the Effect of Estimate Provisions Therein, 28 CoLUM. L. REv. 223 (1928) [hereinafter cited as 28 ColuM. L. REv. 223];

Note, Requirements Contracts Under the Uniform Commercial Code, 102 U. PA. L. Rev. 654 (1954) [hereinafter cited as 102 U. PA. L. REv. 654]. 
it might be expected that controversy would follow from its susceptibility to an interpretation which would upset a developing and seemingly desirable trend in prior law. This has not happened, and the consequence has been the uncontroversial initiation of a new venture in statutory control which may seriously undermine the commercial utility of open-quantity contracts in their traditional forms.

At the basis of the controversy under section 2-306 is the issue of whether the level of requirements or output under an open-quantity contract may deviate substantially from contract estimates or from the prior performance level of the quantity-determining party. Prior to the Code, there was considerable support, but by no means a consensus, for the view that the buyer's control over his requirements, and the seller's discretion with respect to his output, were governed by a good faith limitation; that is, the party who had it within his power to give substance to the quantity term had to establish his needs, or output, in good faith and without artificial manipulation. ${ }^{2}$ That there might also be an objective quantitative limitation-such as the level of prior requirements or output-not only lacked significant support in case law, but was negated by implication in the formidable commentary of Williston and Corbin. ${ }^{3}$ The Code, without question, codified the good faith requirements and settled the mild dispute evidenced in prior law. The issue which has generated a divergence of interpretation, however, is identification of the situations in which the Code establishes a quantitative limitation upon output and requirements variations. The text of section 2-306(1) is as follows:

A term which measures the quantity by the output of the seller or the requirements of the buyer means such actual output or requirements as may occur in good faith, except that no quantity unreasonably disproportionate to any stated estimate or in the absence of a stated estimate to any normal or otherwise comparable prior output or requirements may be tendered or demanded. ${ }^{4}$

2. See notes 42-50 infra and accompanying text.

3. 3 CORBIN $\$ 569 ; 2$ WIILISTON $\$ 464(\mathrm{~b})$.

4. UNIFORM COMMERCIAL CODE $§ 2-306(1)$ [hereinafter cited as UCC]. EXcept as otherwise indicated, all references to the Code are to the 1962 Official Text with Comments (West, 1963).

The text of section 2-306(1) suggests the basis for identifying the types of contracts to which the new Code rules will apply. Such contracts are those which include "a term which measures quantity by the output of the seller or requirements of the buyer." The type of contract most clearly within the section is one in which the obligation of the buyer to buy his requirements or the seller to sell his output is not subject to modifying language or figures. See, e.g., Whiting Stoker Co. v. Chicago Stoker Corp., 171 F.2d 248 (7th Cir. 1948), cert. denied, 337 U.S. 915 (1949); Anderson v. La Rinconada Country Club, 4 Cal. App. 2d 197, 40 P.2d 571 (1935); Fuchs 
The Code language establishes a limitation for some variations, but it is not clear whether the limitation applies equally to the four varieties of fluctuation-tliat is, increases in requirements, imcreases in output, decreases in requirements, and decreases in output.

v. United Motor Stage Co., 135 Ohio St. 509, 21 N.E.2d 669 (1939); Hickey v. O'Brien, 123 Mich. 611, 82 N.W. 241 (1900); Elk Ref. Co. v. Falling Rock Channel Coal Co., 92 W. Va. 479, 115 S.E. 431 (1922). However, where a contract includes quantity figures with language which suggests an element of indefiniteness, the issue of the applicability of section 2-306 is raised most sharply. As to one frequently used clause-that specifying the minimum and maximum quantities which may be orderedit has been intimated, in a case not involving the Code, that such an agreement cannot be viewed as a requirement or output contract, apparently because the parties have specified quantity limits which will operate irrespective of the buyer's requirements or the seller's output. See Monohth Portland Cement Co. v. Douglas Oil Co., 303 F.2d 176 (9th Cir. 1962). See also R. ANDERSON, UNIFORM COMMERCIAL CODE $\S 2.306: 3$ (1961). Analysis should reveal, however, that the minimum-maximuin contract and the requirements or output contract may not be mutually exclusive classifications. Rather, the standard governing the buyer's right to order quantities between the stated minimum and maximum must first be determined. Although in a given factual situation, one party may have unlimited discretion to peg the quantity, see, e.g., Diamond Alkali Co. v. Aetna Explosives Co., 264 Pa. 304, 107 A. 711 (1919), the facts surrounding the formation of the contract may indicate that the standard the parties contemplated was the requirements of the buyer or the output of the seller. See, e.g., Loudenback Fertilizer Co. v. Tennessee Phosphate Co., 121 F. 298 (6th Cir. 1903); National Home Products Co. v. Union Carbide \& Carbon Corp., 281 App. Div. 604, 607, 121 N.Y.S.2d 130, 132 (dicta), aff'd mem. 306 N.Y. 638, 116 N.E.2d 245 (1953).

The text of the Code offers no clear answer to the question of whether section 2-306 applies to a minimum-maximum contract and on that basis might give rise to the suggestion that it should be read to apply only to contracts which include "a term which measures the quantity [solely] by output of the seller or requirements of the buyer." Comment 3, however, gives specific mention to contracts otherwise within the section in which the parties estabish a minimum-inaximum range, which should serve to resolve any doubt that the feature determining applicability of the section is not the parties' inclusion of definite quantity figures but rather their intent that performance obligations are to be determined by actual requirements or output. See generally 54 COLUM. L. Rev. 296 (1954).

Another type of contract which requires an analysis of the parties' intent to determine the applicability of section 2-306 is that which includes a specific quantity term qualified by expressions such as "about," "inore or less," or "approximately." See, e.g., Everett Plywood \& Door Corp. v. United States, 419 F.2d 425 (Ct. Cl. 1969) ("more or less"); National Wholesale Grocery Co. v. Mann, 251 Mass. 238, 146 N.E. 791 (1925) ("about"); Spotless Co. v. Commercial Trust Co., 215 App. Div. 412, 214 N.Y.S. 10 (1926) ("approximately"). See generally Annot., 58 A.L.R.2d 377 (1958). The typical use of such qualifying words is to allow for slight variations attributable to only such conditions as difficulty in counting and immaterial loss in shipment. Variations of this sort are not judged by the buyer's requirements or seller's output and the limitations of section 2-306 are not applicable. But a quantity term so stated may be accompanied by other language which indicates that variations are to be determined by a standard which comports with the Code defimition for a requirements or output contract. In such a case, the flexibility of the quantity term is 
While, as pointed out below, the text of the Code itself is susceptible to conflicting interpretations, the ambiguity as to the intended meaning of the section is most clearly illustrated in the explanation given in the Official Comment. Comment 2 states on the one hand that, "under this section, the party who will determine quantity is required to operate his plant . . . so that his output or requirements will approximate a reasonably foreseeable figure." That may mean that a quantity limitation with fairly definite contours, such as that suggested by past levels of need or output, is imposed by the section. The next sentence, however, quickly refutes that implication: "good faith variations from prior requirements are permitted even when the variation may be such as to result in discontinuance." Surely, a provision which sanctions reduction of requirements to a level of discontinuance imposes no limitation at all. But in the next Comment the certainty of that proposition is dispelled. Estimates of outputs or requirements, which, according to the text, stand on the sane level as prior requireinents levels, ${ }^{5}$ are identified "as a center around which the parties intend the variation to occur" and no quantity unreasonably disproportionate to the estimate or prior performance level may be tendered or demanded. Thus, it appears that, contrary to what was said in Comment 2, no significant variation from the "center" quantity level, and certainly not a discontinuance, will be tolerated. Since the estimate or prior performance level is a center, and not a ceiling or a floor, the implication of Comment 3 is that increases or decreases in quantity beyond a reasonably proportionate level will not be permitted. ${ }^{6}$

considerably greater than in the situations first mentioned. Thus, when the government contracted to buy "eight hundred and eighty (880) cords of . . . oak wood, more or less, as shall be determined to be necessary" by the commander of the military post to which it was to be delivered, the United States Supreme Court concluded that the quantity of wood which the buyer must accept was to be determined by his actual requirements. See Brawley v. United States, 96 U.S. 168 (1877). So judged, this type of quantity term meets the definitional standard of section 2-306 and variations in requirements will be determined according to the limitations of that section.

5. The Code disapproves the tendering or demanding of any quantity "unreasonably disproportionate to any stated estimate or in the absence of a stated estimate to any normal or otherwise comparable prior output or requirements." UCC $\& 2$ 306(1) (emphasis added).

Interestingly, Comment 3 speaks only of "estimates" in spite of the textual equation of estimates and prior output or requirements. No explanation of this wording appears, but it may suggest that the Comment drafters believed the case to be made regarding estimates was more convincing than that to be made for prior levels of output or requirements. See UCC \& 2-306, Comment 3. See also note 78 infra.

6. The interpretive dilemma generated by the drafters' language may not be faced in all cases involving variations in requirements or output. If the parties had not imcluded an estimate of the quantity tern in the agreement and if the buyer cannot 
This contradiction has fostered divergent interpretations. To some, the Code presents a limitation, in addition to that flowing from the good faith standard, upon both increases and decreases in requirements or output levels. The most complete statement of this interpretation was made by Professor Honnold for the Study of the Uniform Commercial Code undertaken for the New York Law Revision Commission. ${ }^{7}$ While recognizing the ambiguity of the Code text in the situation where requirements or output are reduced, Professor Honnold observes that "the fact that the Code provision on disproportionate volume is introduced by the word 'except' suggests strongly that this language imposes a qualification on the 'good faith' test." He then hypothesizes a situation in which a dealer in shoes has reduced his orders froin 10,000 to 4,000 pairs a month "due to business conditions." Despite the dealer's "obvious 'good faith," the Study concludes, "under the qualifying language of the text [of section 2-306(1)], it would seem that the buyer would be liable for damages as a result of this 'unreasonably disproportionate' reduction of demand . . .." While this

be said to have an established level of "normal ... prior . . . output or requirements," a variation in quantity can be justified with only a showing that the fluctuation was the result of factors indicative of good faith. The typical case in which there is no prior quantity level established is one in which the business of the quantity-determining party was new. But situations in which a prior quantity level could not be devised by a requirements seller or output buyer would appear to be rare. Indeed, to postulate that a requirements seller or output buyer would object to a variation in consumption or production presupposes that he had been led to expect a different level of demand or supply. The basis of that expectation may serve as the standard against which the relative level of variation could be judged.

Contrary to the suggestion of the Oregon Code Handbook, "normal ... prior ... ontput or requirements" need not be determined solely by reference to the prior course of dealing between the parties. See Oregon State Bar, UNIForm Commercial Code HANDBook 30 (1963). Neither section 2-306(1) nor its Comment so limit the meaning of the phrase, and such a construction is undesirable insofar as it removes from the coverage of the section those situations in which the beginning of the contractual relationship involving an established quantity-determining party preceded by only a short period the variation in quantity. Even though the Code definition of prior course of dealing may not be satisfied in such a situation, see UCC $\$ 1-205(1)$, the pre-contract requirements or output history would seemingly provide an accurate guide for application of the exception proviso of section 2-306(1). See R. NoRDSTROM, HANDBOOK OF THE LAW OF SALES $\S 40$ (1970). Of course, under the construction urged in this article, the meaning of "normal . . . prior . . . requirements" is of no consequence in situations in which requirements are reduced in good faith since the clause is found to be inapplicable. See text accompanying notes 57-93 infra.

7. 1 N.Y. Revision COMm'N, Study of the Uniform Commercial Code 378-79 (1955).

8. Id. at 378. The conclusion of the Study is qualified by a recognition that paragraphs 2 and 3 of the Official Comment present conflicting interpretations of the intended application of the section to good faith reductions. Id. at 378-79.

In the appendices of the subsequently published final Report of the Law Revision 
interpretation has been accepted by others, ${ }^{0}$ it has its dissenters. It has not yet been suggested that increases in requirements or output can be inade free of the quantitative limitation of a contract estimate or past performance levels. It is, however, felt by soine to be unlikely that the Code presents a limitation, other than good faith, on decreases in requirements or output. ${ }^{10}$ The apparent basis of these reservations is the extensive pre-Code judicial and scholarly opinion that unlimited decreases, even to the point of cessation of the business which deterinined quantity level, were permissible. ${ }^{11}$

At least one source has suggested an interpretation which resolves the tension between the general good faith rule and the textual exception restricting disproportionate variations. ${ }^{12}$ The exception proviso would be applicable to all variations in requirements or output, but in

Commission, it is noted that the Commission had considered a suggestion that the exception clause in subsection (1) of section 2-306 be deleted. It was proposed that the parties' obligation under section 2-306 be defined by both the good faith standard and the parties' intention as evidenced by the terms and context of their agreement. 1 N.Y. LaW ReVision COMM'N, REPORT AND APPENDICES ReIating to tHe UNIForm COMMERCIAL CODE 374-75 (1956).

9. The Committee on Continuing Legal Education of the Oregon State Bar is less equivocal in its acceptance of a quantitative limitation on certain requirements reductions:

Whereas the requirements under all output or requirements contracts are restricted by the limits of good faith, further limitation of reasonableness in the extent of variation from anticipation of quantities is imposed where there is either a prior course of dealing between the parties on the basis of which output or requirements could be estimated or an estimate of output or requireunents stated in the agreement. OREGON STATE BAR, supra note 6 , at 30 (emphasis added).

See also 1 R. ANDERson, UNIForm Commerctal Code $\& 2.306: 5$ (1961); 1 W. Hawkind, A Transactional Gutde to the Uniform Commercial Code 51-52 (1964).

10. Support for the view that section 2-306 should be interpreted as not limiting good faith reductions in quantities has come primarily from student commentators. See Note, Requirements Contracts: Problems of Drafting and Construction, 78 HARV. L. Rev. 1212, 1220 (1965); Project, A Comparison of California Sales Law and Art. icle Two of the Uniform Commercial Code, 10 U.C.L.A.L. REv. 1087, 1137 (1963); 102 U. PA. L. Rev. 654, 663-66 (1954).

Others have recognized the ambiguity in the statute. See Duesendero \& KING \& 4.05[2]; Legislative Research COMM'N, Uniform CoMmercial Code: ANalysis of EFFects on Existing Kentucky Law 46 (Research Pub. No. 49, 1957).

11. See, e.g., Oregon Plywood Sales Corp. v. Sutherlin Plywood Corp., 246 F.2d 466 (9th Cir. 1957); Ft. Wayne Corrugated Paper Co. v. Anchor Hocking Glass Corp., 130 F.2d 471 (3d Cir. 1942); Soutbwest Natural Gas Co. v. Oklahoma Portland Cement Co., 102 F.2d 630 (10th Cir. 1939); DuBoff v. Matam Corp., 272 App. Div. 502, 71 N.Y.S.2d 134 (1947); 102 U. PA. L. Rev. at 662-63, 665-66; 28 ColUM. L. Rev. 223, 229.

12. Legislative Research Comm'N, Commonwealth of Kentuckx, supra note 10, at 46-47. The interpretation advanced is that the exception language of section $2-306(1)$ "is simply a restatement of the good faith test and not an additional limita- 
determining whether a disproportionate variation was "unreasonably" so, a court would consider the reason for the reduction and not its relative size. The court could presumably conclude that a change undertaken in good faith would also, at least for Code-sanctioned purposes, be "reasonably" disproportionate, and thus, permissible under the Code. ${ }^{13}$ This approach need not be given serious attention. Despite its other ambiguities, the Code language leaves little doubt that the modifier "unreasonably disproportionate" is intended to describe the quantity of the reduction and is not addressed to motive or causation. Indeed, to read "unreasonably disproportionate" to encompass the qualitative nature of the buyer's action is to render the two clauses of section 2-306(1) largely redundant, for under this approach, the exception proviso would do little more than restate the good faith standard put forth in the first clause of the section. Since the second proviso is introduced by the word "except," the drafters can be considered to have intended to provide a different result in situations within the exception. ${ }^{14}$ Hence, the ambiguity of section 2-306(1) cannot be readily dispelled.

The purpose of this article is to present an interpretative framework which will resolve the conflict in the Comment and clarify the ambiguity of the text. ${ }^{15}$ The theses of this analysis are three. First, the basis of any attempt at analysis should be the commercial function of requirements and output contracts. It can be assumed that codification did not effectuate a drastic limitation on that function, but rather was reflective of it. In particular, it will be assumed that the statute is sensitive to those characteristics which distinguish open-quantity contracts-those for the sale of output or the purchase of require-

tion upon quantitative variations." $I d$. at 46 . The limits of this argument are recognized and discussed in 102 U. PA. L. REv. 654, 663-65.

13. See White \& SUMmers, UNIForm COMMERcial Code \$ 3-8, at 105.

14. See 1 N.Y. Law Revision COMM'N ReporT, supra note 7, at 378 (1972).

15. Except as expressed in the Comment, the legislative history of the text of section 2-306(1) provides no insight into the intended application of the exception proviso. Indeed, the striking feature of the background of the section is a nearly complete absence of modification from its original form. Except for the addition of one minor, nonsubstantive phrase in the fall of 1950, the section appears in the 1962 Official Edition of the Code in precisely the same form as that version first made public in April of 1944. See UNIForm Revised Sales Act $\$ 30$ (Proposed Final Draft No. 1, 1944). This first draft did not include a Comment, although some other sections were accompanied by the drafters' statement. The Comment to the section, however, was written shortly after the draft was released. See UCC \& 2-306, Comment (May, $1949 \mathrm{draft}$ ). Paragraphs 1 and 3 of the Comment remain in substantially the same form as they first appeared. Paragraph 2 was substantially expanded after the $1949 \mathrm{draft}$, and the possible significance of this alteration is discussed below. See notes 78-93 infra and accompanying text. 
ments-from the more traditional fixed-quantity contract. Secondly, and relatedly, because the rule of section $2-306$ is to be a general one applicable to a variety of contracts, it must be interpreted to meet the common needs of these contracts. It is, therefore, preferably general in scope. The danger of too great a specificity is that the legitimate commercial expectations of a party will be subordimated to the sweep of a statutory provision which was designed to cure unrelated problems. In requirements and output contracts, the intentions and expectations of the parties are likely to vary considerably from contract to contract because of significant differences in the parties' ability to predict their requirements or output level. ${ }^{18}$ Thus, it is preferable to frame statutory control to cover only those elements which are clearly shared and to leave the remaining features of the contract subject to the design of the parties' expectations and intentions.

The third thesis is that despite the inherent conflict of the Comment, it is instructive on the question of the likely imtention of those who followed section 2-306 through the several drafts of the Code. Because of limitations on the extent to which the Comments should control the interpretation of the Code, ${ }^{17}$ an analysis based on the Com-

16. Some courts have questioned whether open-quantity contracts can be subject to uniform rules. See William C. Atwater \& Co. v. Terminal Coal Corp., 115 F.2d 887, 888 (1st Cir. 1940): "Requirements contracts cannot all be lumped together in a single category and given an identical legal effect." This view may merely be a recognition that a particular effort should be made to determine the intention of the parties to an open-quantity contract. While the process of judicial interpretation of contracts is generally premised on such a rule, output and requirements arise in such diverse contexts as to justify greater attention to the background of the agreement. The Uniform Commercial Code provides a number of avenues for resort to the context of an agreement. See, e.g., UCC \$§ 1-102(3), -205.

17. Even if the conflict in the Comment is resolved, a question remains as to the weight to be given the Comment. Authorities disagree on the persuasiveness they are willing to assign the Comments. An early draft of the Code itself stated that the Comments "may be consulted in the construction and application of this Act but if text and comment conflict, text controls ...."UCC \& 1-102(3)(f) (1952 draft). However, the present version of the Code contains no textual reference to the Comments.

The Comments cannot be categorized as legislative history for the Code since "[i]n some states the revised Comments had not yet been drafted at the time of the Code's adoption. In others it is highly doubtful that the Comments were laid before the legislators in the form of a committee report explaining the [Code] legislation ...." A. Farnsworth \& J. Honnold, Cases and Materials on Commerctal Law 8-10 ( $2 \mathrm{~d}$ ed. 1968). In addition, the drafting of the Comments was neither undertaken at the request of the adopting legislature, nor subject to its review. The Comments fail also as a precise record of the thoughts and purposes of those who created the model text. Many Comments were prepared or modified either later in time than the accompanying Code text or by an author other than the author of the Code text.

Professors Farnsworth and Honnold suggest that the Comments be given "at 
ment may not be determinative in itself. It may, however, be persuasive when viewed against the background of the policy suggested by the nature of open-quantity contracts.

\section{The Function of ReQUIREMENTS AND OUtPUT CONTRACTS}

Section 2-306 represents a first attempt to identify the common bases of open-quantity contracts. While the operation of the rule may be modified by agreement, ${ }^{18}$ the substance of the section is intended to have general application and, therefore, is presumably responsive to the role which requirements and output contracts fulfill in commercial transactions. If it can be accepted that section 2-306 was drafted in light of the commercial role of such contracts, examination of those functions should provide a general guide for interpretation of the drafters' product. A statute which expresses this function may also reflect policy-based limitations, such as a concern for the impact of drastic, though unanticipated, quantity variations. While the need and prece-

least as much weight as an able article or treatise construing the Code." $I d$. at 10 . They probably deserve greater deference, however. The Comment authors, even where not the actual authors of the accompanymg text, were at least intimately involved in the discussions surrounding the various Code drafts and were in a position to influence and be influenced by the Code drafters. Also, while a treatise author may be in the position of advocating a particular interpretation of the now formalized Code, the Comment writer is concerned primarily with explaining the intentions of the drafting body.

Courts have been relatively unconcerned with this academic debate and seem ready to cite any Comment which seems reasonably compatible with the text; see, e.g., In re Yale Express System, Inc., 370 F.2d 433 (2d Cir. 1966), or which reasonably expands the application of the text; see, e.g., Warren's Kiddie Shoppe, Inc. v. Casual Slacks, Inc., 120 Ga. App. 578, 171 S.E.2d 643 (1969). And where the conflict between text and Comment is real, the Comment is likely to be disregarded. See, e.g., Miller v. Preitz, 422 Pa. 383, 221 A.2d 320 (1966); Zinni v. One Township Line Corp., 36 Pa. D. \& C.2d 297 (Del. County C.P. 1965). But see Miller v. Preitz, 422 Pa. 383, 405,221 A.2d 320, 333 (concurring and dissenting opinion). This approach seems fairly close to the use of the Comments suggested in the 1952 draft. Since both common sense and practicality support this construction, the reticence of the drafters to continue their earlier view is curious. In any case, the present discussion accepts the Comments as legitimate and persuasive authority for interpretation of the Code where there is no clear conflict between text and Comments.

18. UCC $\$ 1-102(3)$ provides in part: "The effect of provisions of this Act may be varied by agreement ...." The purpose of this section is to state "affirmatively at the outset that freedom of contract is a principle of the Code . . ." Id., Comment 2. It is also provided, however, that an obligation of good faith cannot be removed by agreement UCC $\$ 1-102(3)$. Hence, the parties cannot vary the general rule of section 2-306 that the obligation imposed by an open-quantity contract is determined by "such actual output or requirements as may occur in good faith . ..." But even as to the good faith criteria, "the parties may by agreement determine the standards by which the performance of such obligation . . . is to be measured if such standards are not manifestly unreasonable." UCC \$ 1-102(3). 
dent for such limitations are considered later, this initial inquiry is unencumbered by these policy choices, since they, too, inust be responsive to function.

This discussion will atteinpt to define the utility of open-quantity contracts as a form for commercial transactions. Such a definition emphasizes the reasons why a contracting party would choose this type of arrangement rather than the inore typical fixed-quantity contract. In addition, there will be an identification of the extent to which the requireinents or output contract offers distinct advantages in particular situations, advantages which should be preserved if they conform to legal policy.

The present analysis will presume a true requirements or output contract-one for which the sole determinant of quantity is actual requirements or actual output, upon which no significant artificial limitation is imposed by judicial or statutory rule. To simplify the analysis, it will also be assumed that the party whose activity will establish quantity is one who produces a commodity and is thus concerned about the conditions under which he secures equipinent and materials and the condition of the market in which he sells his product. While the cases suggest that other factual patterns are often promment in litigation, ${ }^{10}$ the ultimate analysis will not differ. For purpose of illustration, then, it will be posited that the requirements buyer is a manufacturer of a product which is sold in a unarket of noticeable competition. The buyer requires materials and equipment from various sources and must compete with other buyers of these same commodities. He may seek

19. For instance, sellers may be producers of natural commodities, see, e.g., Southwest Natural Gas Co. v. Oklahoma Portland Cement Co., 102 F.2d 630 (10th Cir. 1939) (natural gas); Rocky Mountain Fuel Co. v. Consolidated Coal \& Coke Co., 276 F. 661 (8th Cir. 1921) (coal); Transcontinental Petroleuin Co. v. Interocean Oil Co., 262 F. 278 (8th Cir. 1919) (crude oil); Tuttle-Cliapman Coal Co. v. Coaldale Fuel Co., 136 Iowa 382, 113 N.W. 827 (1907) (coal); Fayette-Kanawlia Coal Co. v. Lake \& Export Coal Corp., 91 W. Va. 132, 112 S.E. 222 (1922) (coal); or crops, see, e.g., Oldershaw v. Kingsbaker Bros., 53 Cal. App. 667, 200 P. 729 (1921) (tomatoes); Rosenberg v. Rogers, 44 Cal. App. 196, 186 P. 366 (1919) (figs); Liberty Brand Canning Co. v. Denby, 30 Del. 465, 108 A. 142 (1918) (tomatoes); RossVaughan Tobacco Co. v. Johnson, 182 Ky. 325, 206 S.W. 487 (1918) (tobacco); Propst v. William Hanley Co., 94 Ore. 397, 185 P. 766 (1919) (hay); or animals, see, e.g., Longfellow v. Huffman, 55 Ore. 481, 104 P. 961 (1909) (launbs). Also, open-quantity buyers may be jobbers or distributors. See, e.g., Texas Co. v. Pensacola Maritime Corp., 279 F. 19 (5th Cir. 1922); Pittsburgh Plate Glass Co. v. H. Never Glass Co., 253 F. 161 (6th Cir. 1918); Crane v. C. Crane \& Co., 105 F. 869 (7th Cir. 1901); T.W. Jenkins \& Co. v. Anaheim Sugar Co., 237 F. 278 (S.D. Cal. 1916); Trainor v. Buclianan Coal Co., 154 Minn. 204, 191 N.W. 431 (1923); Oscar Schlegel Mfg. Co. v. Peter Cooper's Glue Factory, 231 N.Y. 459, 132 N.E. 148 (1921). 
to have some of his supplies furnished on a requirements basis. Likewise, our illustrative output seller produces a commodity. $\mathrm{He}$ is subject to fluctuations in the cost of his materials and equipment, and, but for the output contract, he would compete with others in the market in which his product is sold.

At the outset, it must be accepted that this is an area in which generalizations are particularly susceptible to significant qualification. A review of business practices reveals that, in fact, open-quantity contracts are used for a variety of reasons and that the function of such contracts is often not viewed in terms of a single, irreducible proposition. This variety also leads to observations which seem contradictory. Thus, in a particular situation it can be said that a buyer chose to frame his agreement as a requirements contract, rather than a fixed-quantity contract, because his needs fluctuated considerably and he would be unable to determine in advance the quantity of a particular commodity which he would ultimately consume. On the other hand, in a different fact situation a requirements contract may be attractive to the seller for the opposite reason. On the basis of past experience, the buyer's requirements may be sufficiently predictable that the seller enters the contract with the expectation that he will be able to devote a predetermined portion of his production to the contract and thus save the marketing expenses which would ordinarily result from the disposition of these goods.

The versatility of the open-quantity contract should suggest, then, that any attempt to identify the function of such arrangements must take the form of a catalogue of the objectives which will be perused by the buyer and seller in various contexts. Once this categorization is completed, an attempt can be made to isolate whatever unifying primciples appear from the variety of commercial objectives identified. The following analysis is in this format.

\section{Production Flexibility}

A true requirements contract allows the buyer to adjust his intake of materials and supplies to fluctuations in markets in which he sells his products or in the markets from which he secures supplies. ${ }^{20}$ As demand for his product decreases, for example, the requirements buyer is both able to reduce his production and to avoid the economic burden of committing capital to unneeded supplies. Similarly, if demand for his product increases, he is able to adjust his production immediately

20. See Havighurst \& Berman, 1-2; 102 U. PA. I. Rev. 654. 
to the extent his supplies are furnished on a requirements basis. Also, if costs for labor and equipment imcrease to the point of seriously impairing profitability, the buyer can respond by reducing production.

The buyer under a fixed-quantity contract, of course, does not necessarily lack a capacity to respond to changes in his markets. The point can be made, however, that the fixed-quantity purchaser is more restricted in his production options. If he secures his supplies through a series of fixed-quantity contracts, he runs the risk, on the one hand, that he will over-purchase. A subsequent contraction in his product market or a price increase in his inarket for other supplies may leave him in a position in which he is legally obligated to accept goods which he does not need immediately. The resources which are necessary to meet that commitment might have more profitably been applied to other aspects of his busmess. On the other hand, the fixed-quantity purchaser at other times may find that his fixed-quantity arrangements have resulted in his purchasing insufficient quantities. When deinand for his product imcreases, he can, of course, enter additional contracts to satisfy his needs. But in doing so, he faces the risk of a price increase, a risk which could be avoided, or at least controlled within manageable limits, by an appropriately drafted requirements contract.

In short, a requirements contract can serve as a risk-shifting device. By his utilization of this form of agreement, the buyer can shift to the requirements seller soine of the risks of the buyer's business. Among the most important of these is the risk that the market in which the buyer sells his product will contract. ${ }^{21}$ And the seller who agrees to a fixed-price requirements arrangement also accepts the risk that the market price for his commodity will increase and thus he must forego potential opportunities for more profitable sales to other buyers. ${ }^{22}$

The extent to which a buyer will seek a requirements contract for the purpose of preserving production flexibility may ultimately depend upon the predictability of his future needs. For the buyer who has a highly stable dennand for a particular commodity, the requirements contract offers little in terms of risk-spreading that could not be secured from a series of fixed-quantity arrangements. As discussed below, a buyer in this situation may select the open-quantity contract for other reasons. But the buyer who faces variable supply needs may find

21. See, e.g., Royal Paper Box Co. v. E.R. Apt Shoe Co., 290 Mass. 207, 210, 195 N.E. 96, 98 (1935); 28 Colum. L. Rev. 223.

22. See Standard Oil Co. v. United States, 337 U.S. 293, 306-07 (1949). 
a substantial advantage in avoiding the nore rigid commitment of a fixed-quantity contractual arrangement.

While the flexibility in production which is assured by a requirements contract may offer a substantial advantage to the buyer, such arrangements must offer some inducement to the seller to accept the risks which the buyer avoids. The nature of the imcentive for the seller will ultimately depend upon his perception of the extent of the risk which he confronts. In the situation in which there is considerable uncertainty as to the buyer's requirements, the means which the seller will most likely use is a price adjustment; he can use the fact of his riskassumption as a basis for bargaining for a selling price above that of the then established market price. ${ }^{23}$ While this would seem to be the most typically apphicable means for compensating the seller, there are other features of the arrangement which may be attractive. As the rate of the requirements buyer's consumption becomes more predictable, price adjustments are less likely and these other considerations presumably will play a greater role. The seller may anticipate, for example, that the buyer will buy the contract goods in sufficiently large quantities that he is compensated for the risk of a quantity fluctuation. ${ }^{24}$ The guaranteed market of the requirements contract will relieve the seller of the burden of pursuing other markets and may yield a substantial reduction in selling expenses. ${ }^{25}$ Similarly, a predictable demand will assist the seller in planning for his business and permit the more efficient allocation of resources.

From the seller's perspective, the requirements contract also has the effect of excluding other competitors froin the outlet which he has secured. Where the seller already holds a dominant market position, this attribute may have serious antitrust implications. ${ }^{28}$ In other situa-

23. See Shader Contractors, Inc. v. United States, 276 F.2d 1, 7 (Ct. Cl. 1960); 3 CORBIN $\$ 569$, at 341 . Cf. 2 WIIIISTON $\$ 464$ (d).

24. See Havighurst \& Berman 2.

25. See Standard Oil Co. v. United States, 337 U.S. 293, 306 (1949). See also 26 IND. L.J. 111, 113-14 (1950).

26. A requirements contract may violate the antitrust laws when the market position thereby acquired by the seller in a given area is such that it would effectively foreclose competition in a substantial share of the line of commerce affected. See Clayton Act § 3, 15 U.S.C. \$ 14 (1970). See generally Tampa Elec. Co. v. Nashville Coal Co., 365 U.S. 320 (1961); Standard Oil Co. v. United States, 337 U.S. 293 (1949); Fargo Glass \& Paint Co. v. Globe Am. Corp., 201 F.2d 534 (7th Cir. 1953); Aluminum Shapes, Inc. v. K-A-Liquidating Co., 290 F. Supp. 356 (W.D. Pa. 1968); United States v. Richfield Oil Corp., 99 F. Supp. 280 (S.D. Cal. 1951), aff'd per curiam, 343 U.S. 922 (1952); P. AREEDA, ANTITRUST ANALYSIS 488-89 (1956); Bok, The Tampa Electric Case and the Problem of Exclusive Arrangements Under the Clayton Act, 1961 SUP. CT. REv. 267; Helman, Partial Requirements Contracts Under Section Three of the Clayton Act, 55 Nw. U.L. REv. 288 (1960); Lockhart \& Sacks, 
tions, the effect of the open-quantity contract in restricting competition may be quite desirable, for a seller who is a new entrant into an established product market may be attracted by the protection which the requirements contract provides. If the market is already occupied by established sellers, a prospective competitor may be unwilling to enter it unless lie secures a protected market, such as that provided by a requirements buyer with a stable demand. When the seller has secured such a contract, the decision to commit resources to the development of a market position can be made with an assurance that a demand will exist for the seller's product. In this situation, the seller exchanges the risk of his own lack of competitiveness during the start-up period for what he may perceive as a lesser risk that his prediction of the buyer's demands will prove to be inaccurate.

Much of the analysis concerning the importance of production flexibility to the requirements buyer can also be applied to the seller under an output contract. Such a contract, from the perspective of the seller, has the attraction of insuring a constant demand for his product. It is true, as accepted by traditional analysis, that the advantage of such a contract likely to be given highest priority by the seller is the savings of marketing costs which flows from the assured demand. ${ }^{27}$ Indeed, the articulated expectations of the seller are likely to emphasize this cost-saving feature. If the arrangement is a true output contract, however, it will afford the seller greater freedom to control the production levels of his operation than might be available if his sales were limited to fixed-quantity orders. If the seller's only obligation is to sell his output, production volume can be adjusted to insure that the goods are produced at a level which achieves maximum profitability in his plant. If the cost of supplies increases and it is necessary to increase the volume of production to further spread these costs, the seller is assured that a market will exist for the commodities produced. Were the seller's product marketed only through fixedquantity contracts, the desired result could be achieved only if the seller could locate or stimulate demand from other buyers. If production of the commodity becomes unprofitable due to material shortages or imcreased costs, the seller will reduce his output, assuming that he is permitted to do so by applicable legal constraints. If he were bound

The Relevance of Economic Factors in Determining Whether Exclusive Arrangements Violate Section 3 of the Clayton Act, 65 HARv. L. Rev. 913 (1952).

27. See Havighurst \& Berman 2; 102 U. PA. L. Rev. 654. Cf. Standard Oil Co. v. United States, 337 U.S. 293, 306 (1949); Stockhausen, The Commercial and AntiTrust Aspects of Term Requirements Contracts, 23 N.Y.U.L. REv. 412 (1948). 
under a series of fixed-quantity contracts, he would not have this option and would be forced to continue production to the extent necessary to meet pre-existing commitments. Because of this and other advantages to the seller, the buyer is likely to be able to secure a more favorable price for the commodity sold than would be available in the open market at the time of the contract. A basic assumption of this arrangement is, however, that the potential for profit will prompt the seller to maintain production whenever feasible. ${ }^{28}$ Hence, the buyer's assessment of the risk he assumes-and, thus, his desire for a price advantage-reflect the weight of this consideration as well as such factors as the seller's prior output levels, the capacity of his plant, and the availability of his supplies.

Thus, a central feature of both output and requirements contracts in their pristine forms is the flexibility which is afforded the quantitydetermining party in the operation of his business. When business reversals arise, the party is in a position to adjust his production to minimize the risk of financial loss. Similarly, the open-quantity arrangement allows the quantity-determining party to respond when there is an opportunity for greater profits. ${ }^{29}$ Thus, in addition to other advantages, the requirements buyer or output seller retains a capacity to respond to changes in the profitability of his business, and thereby achieves an objective which is central to any commercial operation. While the quantity-determining party in these capacities will often trade off other advantages-usually price-to maintain the desired flexibility, resort to the open-quantity contract offers greater flexibility of busmess operation than would exist under fixed-quantity arrangements in which obligation to accept some goods-or right to demand additional quantities-is predetermined.

\section{Other Functions}

Open-quantity contracts serve commercial functions other than assuring the quantity-determining party flexibility in establishing the production level of his busmess. These include minimization of supply

\section{See note 54 infra.}

29. The cause of decreased profitability might be the open-quantity contract itself, when it is a fixed-price contract with a contract price above the prevailing market. There has been a general rejection of the idea that a legitimate function of an openquantity contract is to allow avoidance of the contract merely because its terms become unfavorable. Rather, the cause of a change in the prospect for profitability must have origins independent of the contract itself. See, e.g., Loudenback Fertilizer Co. v. Tennessee Phosphate Co., 121 F. 298 (6th Cir. 1903); Note, supra note 10, at 122223; 102 U. PA. L. REV. 654, 658-60. 
risks other than those identified above, achievement of greater operational efficiency, and reduction of direct operational costs. In particular cases, these other functions may be the feature which ultimately attracts a party to the arrangement, although it is often the case that this contractual form is used to satisfy a mixture of motives which encompasses both the flexibility function and one or more of those discussed herein. There is likely to be considerable variation in the degree to which each of these functions is represented in the articulated expectations of particular buyers and sellers. ${ }^{30}$ And, in many cases, a function may be assumed but not expressly identified by the quantity-determining party. In other situations, the circumstances of the contractual setting will suggest that a function is not operative.

Minimization of supply risks. For a particular manufacturer, there may be a substantial risk that the availability of material will be restricted. $^{31}$ The cause may be supply limitations which exist irrespective of price, as in the case of scarce natural resources, or which are related to the presence of unpredictably fluctuating cost. By resort to a requirements contract, the purchaser can surmount these supply risks. The buyer is locked into a source of supply and assured that the seller will not market a product of limited availability to other buyers.

30. For example, in some situations the choice of a requirements contract must be explained primarily from the perspective of the seller. The requirements contracts found in merchandise and food franchising are often of this sort. The requirements obligation which the franchisee-buyer assumes may be only an incidental consequence of his desire to secure other advantages which flow from association with the franchisor. Hence, the primary attraction to the franchisee may be the opportunity to use the franchisor's trademark or other evidence of goodwill; to secure the franchisor's assistance in busmess management and product promotion; or to receive preferences with respect to particular territories or customers. In order to secure these opportunities, the franchisee may not be able or inclined to bargain separately about the extent of his requirements obligation. Cf. Gellhorn, Limitations on Contract Termination Rights-Franchise Cancellation, 1967 DUKE L.J. 465, 468 n.8. Even where this is the case, the franchise requirements contract will fulfill for the buyer some of the functions identified in this article. Thus, the buyer will be able to shift some market risks to the franchisor and his contract may also increase his operational efficiency and produce some direct cost savings. And, obviously, a constant source of supply will be secured. But the role of the requirements contract in this context is often more realistically viewed in terms of the seller's objectives. The seller may impose the contract in order to preserve the integrity of his product or trademark or merely to limit the franchisor's right to purchase from other sourcesconsiderations which may be subject to scrutiny under the antitrust laws. See generally D. ThOMPSON, FRANCHISE OPERATIONS AND ANTTTRUST (1971) and authorities cited in note 26 supra.

31. See Wilson v. Corrugated Kraft Containers, 117 Cal. App. 749, 256 P.2d 1012 (Dist. Ct. App. 1953) (scarcity of boxes due to military demands); Nickel v. Theresa Farmer's Co-op Ass'n, 247 Wis. 412, 20 N.W.2d 117 (1945). 
Where the buyer's concern is with future fluctuations in market price, a fixed-price requirements contract will provide protection from that uncertainty.

It should be apparent that a fixed-quantity contract could also be used to preserve a source of supply. The utility of such an arrangement, however, would approximate that of the open-quantity contract ouly in the situation in which the buyer could predict his needs with precision. Where the buyer is attempting to meet short-term supply needs, he may very well find that the requirements contract offers no particular advantage in securing his supply source. If the buyer's concern for the quality or availability of his supplies extends over a longer term, however, the element of predictability is less certain. In this situtation the choice of a requirements arrangement can serve both to secure the needed supplies and permit flexibility in the rate of consumption. The buyer could, of course, attempt to satisfy his long-term requirements by a series of fixed-quantity contracts in which a new contract was negotiated as his supply needs became susceptible to a reasonably accurate projection. Such an approach would, however, offer a number of disadvantages. In addition to the possibility of an over- or under-purchase of goods, the buyer would not only incur transactions costs-which, as explained below, include the cost of seeking out and negotiating with sellers-but would also expose himself to price increases. A requirements contract could be used to avoid these difficulties.

The seller under an output contract also gains advantages in the market from which he secures supplies. The output contract assures a constant demand, a feature which is not present where the seller relies on fixed-quantity sales to dispose of his production. To meet that demand, the seller can produce his product at an even rate and his supply needs will have greater stability than would exist were he not competing in a guaranteed market. He can use this feature of a constant and predictable consumption level as a basis for bargaining for an advantageous price arrangement with his suppliers. The supplier shares in the advantage of the output contract by receiving some protection against his own over-production.

Increased operational efficiency. The ability of the output seller to operate his plant more efficiently is apparent: the seller's rate of production can be stabilized, thus insuring efficient use of his labor force, equipment, and physical facilities. ${ }^{32}$ Unlike the seller who

32. See Stockhausen, supra note 27 , at 414 . 
must respond to a varying demand, the output seller can make extensive use of short- and long-term planning for the most productive operation of his business. The buyer under a requirements contract can also increase his operational efficiency and may commit himself to such an arrangement with that objective. He is assured that his supply of materials will be constant, which in turn allows him greater control of his production schedule than would exist if he were forced to secure his supplies through periodic negotiations with suppliers. Variations in the availability of the material, which might otherwise affect the buyer's ability to arrive at an even production schedule, are avoided. In addition, the buyer may substantially enhance the predictability of his cost if he can secure his requirements on a fixed-price basis. By isolating some of his costs in advance of production, he can plan for more efficient allocation of his other resources. Consistent with a theme developed above, similar results could be achieved under fixedquantity contracts only where supply needs could be accurately projected, a condition not likely to be found over a long term.

Decreased direct operational cost. While mcreased operational efficiency will produce cost savings, cost reduction of a more direct sort can be identified as flowing froin an open-quantity arrangement. Once a source of supply is secured under an open-quantity contract, the requireinents buyer no longer needs to devote time or personnel to searching out suppliers and negotiating materials contracts. Moreover, a buyer who attempts to satisfy uncertain supply needs by fixedquantity contracts is likely to make purchases in quantities greater than those needed for immediate consumption in order to minimize both transactions costs and the risk of price variations. The resulting expenditures for storage and maintenance of imventory could be more closely controlled by a requirements arrangement in which the level of periodic orders reflects short-term needs. ${ }^{33}$

The cost reduction which the output seller experiences is more certain. Indeed, it is this function which is often regarded as that which attracts the seller to an output contract. Assured of a steady demand for his production, he need not incur the costs which are usually necessary to stimulate and respond to demand. ${ }^{34}$ Thus, he need not advertise or otherwise promote his product and he need not employ personnel to negotiate and administer sales contracts.

33. See id. at 413.

34. See authorities cited in note 27 supra. 


\section{Relationship of the Various Functions}

The above analysis suggests that a party may negotiate an openquantity contract to take advantage of one or more of the functions of such arrangements. The question can be raised as to whether, for purposes of policy analysis, any ordering can be ascribed to the relative importance of the various functions. It must be accepted that a priority which a quantity-determining party articulates will reflect the peculiar features of the commercial setting in which he operates and, thus, may not be susceptible to generalization. Nonetheless, in terms of the general commercial role fulfilled by open-quantity contracts, it appears that the predommant function is that which permits the quantity-determining party flexibility in determining his level of consunption or output, for it is this feature which ultimately distinguishes this contractual form from the more typical fixed-quantity arrangement.

As has been suggested above, the distinctiveness of other functions of open-quantity contracts is dependent upon retention by the requirements buyer or output seller of some freedom in establishing quantity levels. Thus, a buyer who seeks to reheve himself of the costs of negotiating and administering supply contracts will have a rational basis for choosing a requirements contract only if he is unable to predict his consumption needs with precision. If his needs were certain, as where he is purchasing for a single, short-term project, whatever operational cost savings would result from a requirements contract could be readily duplicated by a carefully planned fixed-quantity agreennent. A buyer might, of course, choose a requirements contract in this situation, but it could not be said that a distinctive commercial objective was fulfilled by that decision.

It is suggested then that even when the articulated priority of production flexibility is not great, the quantity-determining party will likely enter the contract on the unstated assumption that he retains control of his requirements or output. The capacity of a party to secure an advantage from minimization of supply risks, increases in operational efficiency, and cost reduction depends ultimately upon his ability to control the quantities which fulfill the contractual obligation. If quantities can be determined according to needs or output, then the utility of the other features of the contract can be maximized.

In large measure, this analysis might appear to be little more than an elaboration of the obvious: when parties choose to enter an agreement which does not specify a definite quantity, they apparently assume that one party will have some power to define the obligation under the contract. Where the referent for determining quantity is one party's 
requirements or output, without greater specification, whatever freedom is reserved must have been reserved to that party. Despite its obviousness, the point is of considerable importance because it can readily be obscured in judicial and legislative policy-making. It is clear in some cases, for example, that the most immediate attraction of an open-quantity contract for one party was some reason other than the desire for wide-ranging discretion in determining the quantity which would fulfill the contractual obligation. A typical example of such an alternative motive is where the scarcity of a given commodity motivates a user of that commodity to enter into a requirements contract to assure his supply. ${ }^{35}$ This type of situation is readily susceptible to an interpretation which subverts the more fundamental function of openquantity agreements, that of reserving to one party considerable leeway in defining the obligation imposed, in that the exigencies of the particular case may result in a more narrow judicial focus. To avoid that result, and thus to place open-quantity contracts in their proper perspective, the element of quantity flexibility should be the sine qua non in determinations of legal policy in this area.

\section{Contract Law and the Function of Open-Quantity Contracts}

The above discussion with respect to the functions of open-quantity contracts can be read as a strong statement of the desirability of these arrangements for the quantity-determining party. Yet, affording the requirements buyer or an output seller production flexibility represents an extreme risk for the party who must supply the goods or purchase the output. Such contracts, if enforced to the letter without equitable restraint, may produce instances of severe oppression, verging on the unconscionable-as where unforeseen circumstances result in output far in excess of the reasonable expectations of the "lockedin" buyer. ${ }^{36}$ Additionally, a large investment in production equipment for the requirements seller or a structure for goods distribution for the output buyer may be left idle because of a change in the other party's perception of market conditions. Consideration of this potential detriment has promoted limitations in several forms.

35. See, e.g., Wilson v. Corrugated Kraft Containers, 117 Cal. App. 749, 256 P.2d 1012 (Dist. Ct. App. 1953) (period of great scarcity in supply of corrugated boxes caused wholesale jobber to enter requirements contract).

36. See, e.g., Eustis Mining Co. v. Beer, Sondheimer \& Co., 239 F. 976 (S.D.N.Y. 1917), where the court's rigid enforcement of an output contract forced the reluctant buyer to purchase an unforeseeably large amount of cinders, which were the by-product of stepped-up war production. See notes 92-93 infra and accompanying text. It is doubtful that the decision would be upheld under current Code analysis. See notes 107-08 infra and accompanying text. 
Limitation by agreement. Many limitations are added by the parties themselves and are either expressed in the particular terms of their agreement or are implied from the circumstances surrounding the transaction. Thus, there may be resort to a clause specifying the nnarket conditions which serve to limit responsiveness or similar devices. But the particularized nature of these arrangements removes them from the class of open-quantity contracts which should be covered by a general statutory rule and their varieties will not be discussed. It should be noted, however, that the Uniform Commercial Code specifically invites the parties to structure their own arrangement with attention to the general directives of section 2-306. ${ }^{37}$ This is, of course, an implicit recognition that the rule of the section may not be adaptable to all the varieties of situations in which resort is made to the open-quantity contract. But in addition, the invitation for individualized variations suggests that the contracting parties have considerable control over the potential harshness of their agreement.

Limitation by law: The common law approach. In light of the potentially devastating results for the promisee under a requirements or output commitment, it might be thought that judicial construction would lead to appropriate limitations upon the quantity of goods required under these agreements. In fact, there was significant support for the opposite view: that the party who had bargained for production flexibility should be allowed to take full advantage of that feature. ${ }^{38}$ As recently as the latest revision of his treatise, Professor Corbim had no great difficulty with this result, although his footnotes belie the staunchness of the position taken in his text. In summarizing what courts had done with respect to decreases in requirements and output, for example, he wrote:

Does the buyer promise "by implication" that he will have any needs or requirements, that he will send in orders during the whole stated period for the amount of goods that he has used in the past or . . . that he will not fail to keep his business running with its accustoned needs and requirements? . . . . [D]oes the seller promise by implication that he will lave any "output", that he will run his factory or work his mine, with diligence according to past custom, or at all ${ }^{39}$

37. See UCC \& 1-102(3).

38. See, e.g., text accompanying note 99 infra.

39. 3 CORBIN $\& 569$. See also Corbin, The Effect of Options on Consideration, 34 YaLe L.J. 571, 579-83 (1925).

Williston observed that "It is possible . . . that the agreement of the buyer is to take all the goods that his business, if maintained under substantially the same couditious as exist at the time of the bargam, would require; and then, even if he sold his business or discontinued it, he would still be bound to continue purchases. This inter- 
In both of these classes of cases, the courts have generally answered the questions in the negative.40

And Professor Corbin accepts their response. He has no difficulty with the reasonableness of the assumption that the promisee will be willing to bear the risk of there being no output or requirements. In his view, the promisee "can adjust his prices in proportion to the risk." 41

As Professor Corbin's note material recognizes, and apparently approves, many common law courts were uneasy with this unbridled discretion in the quantity-determining party. ${ }^{42} \mathrm{~A}$ doctrine which gave expression to this concern was that which required that changes in requirements or output be undertaken in good faith. Froin many of the contexts in which this phrase is discussed, it appears that its assertion was a response to the fear which plagued earlier courts that mere whim could guide the establishment of quantity levels. ${ }^{43}$ Although the doubts which the earlier courts had had about the mutuality of these contracts were generally settled, ${ }^{44}$ the good faith requirement was a

pretation, however, does not seem the proper one in ordinary cases where the buyer agrees to take what he 'requires,' 'needs,' or 'wants.' " 2 WILLISTON $\$ 464$ (b).

40. See, e.g., cases cited note 11 supra and note 96 infra.

41. 3 CORBIN $\$ 569$, at 341 .

42. See id. $\$ 569$ n.93.

43. See New York Cent. Ironworks Co. v. United States Radiator Co., 174 N.Y. 331, 335, 66 N.E. 967-68 (1903): "[W]e do not mean that the plaintiff had the right, under the contract, to order goods to any amount . . . . The obligation of good faith and fair dealing . . . is implied in every contract of this character. The plaintiff could not use the contract for the purpose of speculation in a rising market . . . ."

In Fayette-Kanawha Coal Co. v. Lake \& Export Coal Corp., 91 W. Va. 132, 112 S.E. 222 (1922) an output buyer argued that the output contract lacked nuutuality because the seller "could easily avoid its obligation by simply closing down its plant." The court rejected this construction, holding that the seller was under the "obligation to operate these mines in the ordinary way, in good faith . . .." $91 \mathrm{~W}$. Va. at 139-40, 112 S.E. at 225. See also Shader Contractors, Inc. v. United States, 276 F.2d 1, 4 (Ct. Cl. 1960).

44. See 1A Corbin, Contracts $\$ 156$, at 30 n.22 (1963). But see Comment, Muttuality of Obligation in Wisconsin Requirements Contracts: A Suggested Approach Under the Uniform Commercial Code, 1954 Wrs. L. Rev. 684.

The judicial concern for the mutuality of the obligations assumed under an openquantity contract has been the subject of extensive commentary. See generally Corbin, supra note 39, at 579-83; Duesenberg \& KING \& 4.05[1]; 2 Williston $\$ \&$ 464(a)(d); Havighurst \& Berman; Lavery, The Doctrine of Bailey v. Austrian, 10 MinN. L. Rev. 584 (1926); Patterson, "Illusory" Promises and Promisors' Options, 6 IowA L. BuLl. 209 (1921); Note, Species of Inadequacy of Consideration Which Have Induced Judicial Refusal to Attach Obligation to Promise, 27 Colum. L. Rev. 178 (1927); Note, supra note 10, at 1213; 102 U. PA. L. REv. 654, 655-57; 48 Mich. L. REV. 362 (1948); 15 MINN. L. REv. 469 (1931); 26 IND. L.J. 111 (1950).

Judicial skepticism about the enforceability of open-quantity contracts has had surprising durability. See Sealtest S. Dairies Division v. Evans, 103 Ga. App. 835, 120 S.E.2d 887 (1961). 
healthy remnant of an age of skepticism. There were few courts which specifically found an absence of good faith, and thus the limits of the term were never tested. ${ }^{45}$ Nonetheless, much of the definitional language of the opinions suggests that good faith would be found if a party acted in accordance with recognized business standards. ${ }^{46}$ In addition, a necessary, although often unarticulated, aspect of the good faith concept was that it did not permit a quantity variation the sole purpose of which was to avoid or take undue advantage of the contract. ${ }^{47}$

This construction, which required independent and dispassionate business influences upon quantity levels, although not logically compelled, did serve a most useful purpose. Its effect was to limit the risks which the requirements seller and output buyer assumed to those of a busmess nature. ${ }^{48}$ While even as redefined these risks covered a wide

45. For two pre-Code cases in which the quantity-determining party was said to have acted in bad faith in demanding excessive quantities for speculative purposes, see Asahel Wheeler Co. v. Mandelson, 180 App. Div. 9, 167 N.Y.S. 435 (Sup. Ct. 1917) and Moore v. American Molasses Co., 106 Misc. 263, 174 N.Y. Supp. 440 (Sup. Ct. 1919); cf. Loudenback Fertilizer Co. v. Tennessee Phosphate Co., 121 F. 298 (6th Cir. 1903). Under the Code, at least one court has considered a case in which the good faith standard of section 2-306 had not been met. See Massachusetts Gas \& Elec. Light Supply Corp. v. V-M Corp., 387 F.2d 605 (1st Cir. 1967).

In several pre-Code cases, courts specifically found the requisite good faith on the part of the quantity-determining party. See, e.g., HML Corp. v. General Foods Corp., 365 F.2d 77 (3d Cir. 1966); Oregon Plywood Sales Corp. v. Sutherlin Plywood Corp., 246 F.2d 466 (9th Cir. 1957); Keener Oil \& Gas Co. v. Consolidated Gas Util. Corp., 190 F.2d 985 (10th Cir. 1951); William C. Atwater \& Co., Inc. v. Terminal Coal Corp., 115 F.2d 887 (1st Cir. 1940); In re United Cigar Stores Co. of America, 72 F.2d 673 (2d Cir. 1934); Neofotistos v. Harvard Brewing Co., 341 Mass. 684, 171 N.E.2d 865 (1961); Dickey v. Philadelphia Minit-Man Corp., 377 Pa. 549, 105 A.2d 580 (1954); Berkeley Connty Public Serv. Dist. v. Vitro Corp. of Am. 152 W. Va. 252, 162 S.E.2d 189 (1968).

46. See Southwest Natural Gas Co. v. Oklahoma Portland Cement Co., 102 F.2d 630, 633 (10th Cir. 1939); In re United Cigar Stores Co. of America, 72 F.2d 673, 675 (2d Cir. 1934); New York Cent. Ironworks Co. v. United States Radiator Co., 174 N.Y. 331, 335, 66 N.E. 967, 1968 (1903). See also text accompanying notes 71-72 infra.

47. See, e.g., Moore v. American Molasses Co., 106 Misc. 263 (1919), 174 N.Y.S. 440; Asahel Wheeler Co. v. Mandelson, 180 App. Div. 9, 167 N.Y.S. 435 (1917). Cf. Loudenback Fertilizer Co. v. Tennessee Phosphate Co., 121 F. 298, 303 (6th Cir. 1903); Waddell v. Phillips, 133 Md. 497, 105 Atl. 771 (1919); Snrith v. Donk Bros. Coal \& Coke, 260 S.W. 545 (Mo. Ct. App. 1924); Oscar Schlegel Mfg. Co. v. Peter Cooper's Glne Factory, 231 N.Y. 459, 132 N.E. 148 (1921).

48. The quantity term miglit seem to be extremely flexible even when only risks of a business nature are assumed. However, the nature and extent of the quantitydetermining party's business will provide the boundaries within which the contract will likely be performed. Particularly where the party is engaged in an established business, he will usually not drastically increase or decrease the quantity under the contract absent fortuitous circumstances. See, e.g., Excelsior Wrapper Co. v. Messinger, 116 Wis. 549, 555-56, 93 N.W. 459 (1903); 28 CoLUM. L. REV. 223, 224-25. 
spectrum, they are more readily anticipated than the risk of personal whim and, thus, can more easily be reflected in the price which the promisee demands.

The good faith requirement continues under the Code and, in the context of most open-quantity contracts, retains its risk-defining function. Under section 2-306, the level of requirements or output must usually be established in accordance with reasonable commercial practices. ${ }^{49}$ Others have taken on the task of giving content to the good faith criteria. ${ }^{50}$

\section{Open-QuANTITy CONTRACTs UNDER SECTION 2-306}

The Code provision on output and requirements contracts does more than merely codify the good faith requirement. It also specifies that even if this condition is satisfied, "no quantity unreasonably disproportionate to any stated estimate or in the absence of a stated estimate to any normal or otherwise comparable prior output or requirements may be tendered or demanded." The obfuscating structure of this language masks its potential impact on the functions of openquantity contracts. It is this language which has prompted the interpretation by some that, under the Code, reasonable proportionality is a

49. As generally applied throughout the Code, good faith means "honesty in fact in the conduct or transaction concerned." UCC \& 1-201(19). In transactions arising under Article 2 which involve one who is a merchant, a more objective standard is applicable. "'Good faith' in the case of a mercliant means loonesty in fact and the observance of reasonable commercial standards of fair dealing in the trade." UCC $\S 2-103(1)(b)$. See, e.g., Stanley v. Fabricators, Inc., 459 P.2d 467, 474 (Alas. 1969); Sherrock v. Commercial Credit Corp., 269 A.2d 407, 408 (Del. Super. Ct. 1970); Columbus Milk Producers' Cooperative v. Department of Agriculture, 48 Wis. $2 d$ 451, 180 N.W.2d 617 (1970); Mattek v. Malofsky, 42 Wis. 2d 16, 165 N.W.2d 406 (1969). The person typically involved in a requirements contract is a merchant since the contract itself assumes an on-going operation. "Mercliant" is defined iu section 2104(1) as "a person wlio deals in goods of the kind or otherwise by his occupation holds himself out as lraving knowledge or skill peculiar to the practices or goods involved in the transaction or to whom such knowledge or skill may be attributed by his employment of an agent or broker or other intermediary who by his occupation holds himself out as having such knowledge or skill." See, e.g., Associated Hardware Supply Co. v. Big Wheel Distrib. Co., 355 F.2d 114 (3d Cir. 1966); Makransky v. Long Island Reo Truck Co., 58 Misc. 2d 338, 295 N.Y.S.2d 240 (1968). But see Cook Grains v. Fallis, 239 Ark. 962, 395 S.W.2d 555 (1965).

50. For a detailed treatment of the good faith concept, see generally DUESENBerg \& KING § 4.08[3] [a]; R. NoRDstrom, supra note 6, § 40; Eisenberg, Good Faith Under the Uniform Commercial Code-A New Look at an Old Problem, 54 MARQ. L. Rev. 1 (1971); Farnsworth, Good Faith Performance and Commercial Reasonableness Under the Uniform Commercial Code, 30 U. CHI. L. Rev. 666 (1963); and Summers, "Good Faith" in General Contract Law and the Sales Provisions of the Uniform Commercial Code, 54 VA. L. Rev. 195 (1968). 
limitation upon increases and decreases in requirements and output. ${ }^{51}$ This view works a fundamental and drastic change of the law of most states. $^{52}$ Moreover, if the quantity-determining party is bound to at least the proximate level of his past consumption or production, his ability to respond to changes in the profitability of his business is significantly reduced. Under this vew of the Code, the quantity-determining party's capacity to adjust his level of production remains only within a limited range around the level of past quantities or contract estimates. In effect, production flexibility as a commercial function is made a considerably less attractive feature than it was in either the pristine setting of the analysis given above or in the perspective of the venerable Professor Corbin.

The desirability of this interpretation can be questioned. First, because of the dependent relationship of the functions, the potential advantages other than production flexibility will be severely restricted, with the result that the commercial utility of this contractual form will be eliminated in many situations. Relatedly, the interpretation lessens the distinction between open- and fixed-quantity contracts. If a party is bound to the approximate level of his past performance, then there is only marginal value in not choosing the fixed-quantity form with its likely price advantage. ${ }^{53}$ Since these two types of arrangements do not have a common commercial purpose, the wisdoin of legislating their similarity is not apparent. Finally, while the objective of the pervasive limitation found by some is undoubtedly to protect the one party from a sudden and drastic change in the quantity level, it is not clear that this protection is appropriately the subject of statutory prohibition. This is the sort of risk which can often be counterbalanced by the price paid by the quantity-determining party. Moreover, where the concern is for decreases in quantity, the need for protection of the requirements seller or output buyer is less compelling. As profit-maximization is in the self-interest of the party who determines quantity, his inclination will be to continue in operation whenever possible, a tendency which tempers the risk of cessation. ${ }^{54}$

51. See authorities cited in notes 7-9 supra.

52. See notes $68-71$ infra and accompanying text.

53. For example, with such a limitation on the flexibility of open-quantity contracts, the requirements buyer who is susceptible to a drastic reduction in his needs may find it more advantageous to operate under a series of small fixed-quantity contracts negotiated to fill short-term supply needs.

54. The early view that a promise to purchase requirements or output lacked mutuality was premised on the notion that the quantity-determining party could easily avoid the contract by simply arranging his affairs so as to have no requirements or output. As is implicitly recognized in the subsequent judicial acceptance of the valid- 
In light of these objections, a question exists as to whether it is likely that those who drafted the Code intended to obligate the quantity-determining party to his prior level of performance. To be sure, in situations where the risk of an undue burden on the requirements seller or output buyer is acute, there may exist a need for a limitation beyond that found in the good faith requirement. But it cannot be shown that the need for such protection is equally compelling for all types of variations. There is a basis in the text and Comment of section 2-306 for reconciling the difficulties which the disputed interpretation raises, while at the same time affirming the drafters' imposition of a quantity limitation where compelled by policy. The premise of this view is that while the drafters chose to treat all types of variations-increases and decreases in both requirements and output-in one section, some indicia of their intent and the dictates of policy suggest that the application of the quantity-limitation is not uniform among these. Rather, considerable support exists for the view that the limitation of the exception proviso of section 2-306 affects only unreasonably disproportionate increases in requirements or output. Decreases in quantity would be limited only by the good faith standard. ${ }^{.5}$

While the analysis presented below will deal with all types of vari-

ity of open-quantity contracts, it is simply not realistic to premise a legal principle on the assumption that decisions as to quantity will be made arbitrarily. Indeed, a more appropriate basis for decision is a realization that, in general, the quantity-determining party's incentive to continue his business represents a very practical limitation on the likelihood that requirements or output will be reduced. The open-quantity contract will typically be merely one aspect of a business which represents a commitment of capital and energy of the party whose performance will define the quantities under the contract. Having made an investment in his business, and, at least temporarily, foregone other opportunities, the party will attempt to continue its operation, either to achieve profitability or to enhance the return of an otherwise profitable business. Those who deal with him can properly assume that he will not casually abandon the endeavor or drastically modify its character. Thus, when the courts devised the rule with respect to requirements contracts that "the seller assumes the risk of all good faith variations in the buyer's requirements even to the extent of a determination to liquidate or discontinue the business," it was recognized that the rule was "based on a reliance on the self-interest of the buyer, who ordinarily will seek to have the largest possible requirements." HMI Corp. v. General Foods Corp., 365 F.2d 77, 81 (3d Cir. 1966). See also 3 Williston $\S 464$ (a), at 741; 28 Colum. L. Rev. 223, 224, n.8.

The quantity-determining party's pursuit of profitability may, of course, mean that in particular situations he will pursue a course which does not benefit the other party. For example, when the requirements buyer finds a less expensive substitute product, he may seek to reduce or eliminate his orders from the requirements seller. It is this type of case in which the requirement of good faith can be invoked to protect the seller's expectation interest. See note 111 infra and accompanying text.

55. See White \& Summers, supra note 13, at 108-09; 102 U. PA. L. Rev. 654, 665-66 (1954). But see Romine, Inc. v. Savannah Steel Co., 117 Ga. App. 353, 160 S.E.2d 659 (1968). 
ations, it must be recognized that there are differences among these four types with respect to both the extent of Comment language and the amount of case precedent relevant to the particular type of fluctuation. In the Comment, for example, only general references are made to output variations, while requirements fluctuations, particularly decreases in requirements, are illustrated in specific examples. In addition, requirements contracts appear to be the more frequently litigated form. ${ }^{56}$

Because of the more extensive Comment language dealing with requirements reductions, analysis of this form more readily reveals the vulnerability of the view that the exception proviso of section 2-306 has equal application among the four types of variation. Further, the more extensive pre-Code case treatment of this form permits more reliable analysis of the policy assumptions of judicial decision. Consequently, analysis of the section as it affects decreases in requirements will be undertaken first and in greatest detail.

\section{Decreases in Requirements}

The factual pattern. Considerations necessitating reduction in the requirements buyer's demand include such factors as decreased product demand, ${ }^{57}$ business interruptions, ${ }^{58}$ technical improvements in production, ${ }^{69}$ and availability of a less expensive substitute for the supplier's material. ${ }^{00}$ But the difficulties with the Code language may be illustrated without discussion at this point of the variety of causes which have prompted prior hitigation. Rather, an appropriate vehicle for discussion of section 2-306(1) is found in the fact situation of Southwest Natural Gas Co. v. Oklahoma Portland Cement Co. ${ }^{61}$ The cement

56. A very general and imprecise survey indicates that the majority of openquantity contracts are those in which quantity is determined by the requirements of the buyer. Compare Annot., 1 A.L.R. 1392 (1919), Annot., 9 A.L.R. 276 (1920), and Anuot., 23 A.L.R. 574 (1923) with Annot., 7 A.L.R. 498 (1920), Annot., 27 A.L.R. 127 (1923), and Annot., 26 A.L.R.2d 1099 (1952). See also Annot., 58 A.L.R.2d 377 (1958).

57. See, e.g., Helena Light \& Ry. v. Northern Pac. Ry., 57 Mont. 93, 186 P. 702 (1920), overruled on other grounds, City of Billings v. Public Serv. Comm'n, 67 Mont. 29, 39, 214 P. 608 (1923); Poston v. Western Dairy Products Co., 129 Waslı. 73, 36 P.2d 65 (1934).

58. See, e.g., William C. Atwater \& Co. v. Terminal Coal Corp., 115 F.2d 887 (1st Cir. 1940); Cragin Prods. Co. v. Fitch, 6 F.2d 557 (8th Cir. 1925).

59. See, e.g., Southwest Natural Gas Co. v. Oklahoma Portland Cement Co., 102 F.2d 630 (10th Cir. 1939).

60. See, e.g., Loudenback Fertilizer Co. v. Tennessee Pliosphate Co., 121 F. 298 (6th Cir. 1903); McKeever, Cook \& Co. v. Canonsburg Iron Co., $138 \mathrm{~Pa} .184,16 \mathrm{~A}$. $97(1890)$.

61. 102 F.2d 630 (10th Cir. 1939). 
company and Southwest's predecessor had entered into an agreement in 1926 under which the gas company was to supply, for a 15-year period, "all 'natural gas as may be needed or required by' the cement company 'for fuel, heating, lighting, power purposes and such other purposes as may be necessary, proper or imcidental to the operation of its plant." ${ }^{32}$ The cement company operation imcluded gas-fired kilns, boilers, and power facilities which, for the period immediately preceding the litigation, consumed approximately 5.3 million cubic feet of gas daily. By subsequent agreement, the cement company was allowed to use up to 3 million cubic feet of gas per day from its own sources. In 1934, the cement company sought to alter its boiler operation by replacing older, independently fired boilers with a new system which utilized the waste heat of cement processing kilns. While the older system required 2.3 million cubic feet of gas for its operation, the new installation would reduce the consumption by as much as 1.9 million cubic feet. Because of the agreement which allowed the cement company to use its own gas supply, the effect of the new operation was to reduce the maximum quantity supplied by the gas company from 2.3 million cubic feet to .4 million cubic feet per day. In its suit to enjoin the use of the new boiler system, the gas company contended that the agreement between the parties prevented a change in the method of the buyer's operation which would drastically reduce its "requirements" of natural gas. While the statement of arguments in the opinion is somewhat incomplete, Southwest's position can be assumed to have been that the cement company was required, for the remainder of the contract term, to maintain its consumption at the previous level of 5.3 million cubic feet per day.

The court concluded that the reduction was the result of a good faith alteration in operation and thus permissible under applicable precedents. $^{63}$ In the court's reading of prior cases, an agreement to purchase one's requirements of a particular commodity did not prevent the purchaser "from exercising judgment and discretion in the conduct of his business or from improving his plant . . .." Noting the unusual duration of the parties' agreeinent, the court found an implied assumption at the time of contracting that existing equipment would require replacement during the contract time and that a modern, more efficient system would be a likely replacement.

62. Id. at 631 .

63. The court found In re United Cigar Stores Co. of America, 72 F.2d 673 (2d Cir.), cert. denied, 293 U.S. 617 (1934), and American \& British Mfg. Corp. v. New Idria Quicksilver Mining Co., 293 F. 509 (1st Cir. 1923) particularly persuasive in this regard.

64. 102 F.2d at 633 . 
The significance of the section 2-306 ambiguities appears most sharply when the two likely interpretations of that provision are applied to the Southwest Natural Gas case. To forestall diversionary assaults upon this application, however, it is necessary that two factors be posited. First, it must be assumed that had the case been decided under the Code, the courts perception of the content of the good faith requirement would have been the same and that a contemporary court could join Judge Phillip's confident conclusion that "[i]n so improving its plant, the Cement Company acted in good faith and in the exercise of prudent business judgement." ${ }^{65}$ Secondly, it must be assumed that the reduction of the buyer's consumption of seller's natural gas from 2.3 to .4 million cubic feet per day resulted in a level of use "unreasonably disproportionate" to "normal or otherwise comparable" requirements. ${ }^{66}$

It is clear that if section 2-306 is interpreted as establishing a twoprong test in this situation-requiring both good faith and a reduction which is not unreasonably disproportionate-the result in Southwest Natural Gas will be reversed. Having failed to satisfy the second facet of the test, the cement company's plant alteration could not have been without legal liability. But such a radical change in the law does not have a readily identifiable policy base. Rather a continuation of the singular good faith standard of pre-Code law is preferable and, some imconsistencies aside, the drafters' product seems to support this result. Indeed, there are obvious difficulties with the argument that Southwest Natural Gas does not continue as valid precedent, for the Comment cites that case approvingly: "Reasonable variation of an extreme sort is exemplified in Southwest Natural Gas Co. v. Oklahoma Portland Cement Co. . . .."

65. $1 d$.

66. The fact that the term "unreasonably disproportionate" is not defined is an obvious invitation to a court to structure its decision to reach a fair result without resort to a mechanical standard. Among the facts likely to be considered in judging whether the reduction in buyer's consumption is "unreasonably disproportionate" are (1) the percentage of the reduction, (2) the effect on profitability, (3) the nature of the buyer's business, and (4) the degree to which the parties originally contemplated that the buyer's needs would fluctuate. See also Whrte \& Summers, supra note 13, $\S 3-8$, at 106 .

67. UCC \$ 2-306, Comment 2.

One point of vulnerability in this analysis of the case is the second assumption set forth above to the effect that the amount of the new gas orders would be found to be "unreasonably disproportionate" to the level of pre-conversion orders. It might be suggested that, since the Comment identifies this as a case of "reasonable variation," it is improper to assume, as was done above, that this was an impermissible variation. A more reasonable construction is that the Comment deemed the variation "reasonable" in a qualitative, and not a quantitative sense. That is, the variation was the 
Prior law. The decision in Southwest Natural Gas is representative of the trend of decisions prior to the Code. Earlier decisions wero divided on the question of the consequence of a drastic reduction in a buyer's requirements and a few later cases have continued to adhere to the view that significant reductions are not permissible. ${ }^{68}$ But the clear trend of more recent, pre-Code cases was to sanction reduction even to cessation. ${ }^{69}$ More persuasive than the sheer number of these cases, however, is their rationale. While the risks accompanying the openquantity contract were specifically recognized, ${ }^{70}$ the decisions reflect the concern that the contract not be interpreted so as to limit the buyer's right to pursue the dictates of his busimess judgment. Although the buyer is bound to buy any requirements he might have froin the seller, "he is left free to deal with his business as he may deem best, provided his conduct is bona fide." ${ }^{\prime 1}$

result of the reasonable actions of the cement company in changing its heating system. Several reasons suggest this result. First, other language of the sentence identifies the variation as one "of an extreme sort." This is the more likely reference to the quantitative degree of change, which was, in fact, extreme. Second, under the two-prong test, that which cannot be "unreasonably disproportionate" is not the present level of the buyer's requirements, but rather the present level of his orders. In Southwest Natural Gas, the buyer had, before the equipment change, ordered 2.3 million cubic feet of natural gas; after the change, he ordered .4 million cubic feet. Surely a reduction of orders to 17 percent of prior orders is an unreasonably disproportionate change.

68. See, e.g., Texas Indus., Inc. v. R.P. Brown, 218 F.2d 510 (5th Cir. 1955); Humble Oil \& Ref. Co. v. Cox, 207 Va. 197, 148 S.E.2d 756 (1966). In Cox, the court recognized that it followed the minority rule in holding that a requirements contract includes an implied promise by the buyer to continue to have requirements during the term of the contract. $207 \mathrm{Va}$. at 204, 148 S.E.2d at 762.

69. See, e.g., HML Corp. v. General Foods Corp., 365 F.2d 77 (3d Cir. 1966); Oregon Plywood Sales Corp. v. Sutherlin Plywood Corp., 246 F.2d 466 (9th Cir. 1957); Ft. Wayne Corrugated Paper Co. v. Anchor Hocking Glass Corp., 130 F.2d 471 (3d Cir. 1942); William C. Atwater \& Co. v. Terminal Coal Corp., 115 F.2d 887 (1st Cir. 1940); In re United Cigar Stores Co. of America, 72 F.2d 673 (2d Cir. 1934); DuBoff v. Matam Corp., 272 App. Div. 502, 71 N.Y.S.2d 134 (1947); Berkeley County Pubhic Serv. Dist. v. Vitro Corp. of America, 152 W. Va. 252, 162 S.E.2d 189 (1968).

70. See, e.g., HML Corp. v. General Foods Corp., 365 F.2d 77, 81 (3d Cir. 1966); In re Umited Cigar Stores Co. of America, 72 F.2d 673, 674-75 (2d Cir. 1934).

71. In re United Cigar Stores Co. of America, 72 F.2d 673, 675 (2d Cir. 1934). A similar attitude is found in William C. Atwater \& Co. v. Terminal Coal Corp., 115 F.2d 887, 888 (1st Cir. 1940); Southwest Natural Gas Co. v. Oklahoma Portland Cement Co., 102 F.2d 630 (10th Cir. 1939); and DuBoff v. Matam Corp., 272 App. Div. 502, 71 N.Y.S.2d 134 (1947). The good faith standard has often been expressed in terms of its relationship to the buyer's business judgment. See, e.g., Berkeley County Public Serv. Dist. v. Vitro Corp. of America, 152 W. Va. 252, 271, 162 S.E.2d 189, 202 (1968) (requirements buyer may alter its operation to eliminate requirements if done "in good faith for valid business reasons"). See also Royal Paper Box Co. v. E.R. Apt Shoe Co., 290 Mass. 207, 210, 195 N.E. 96, 98 (1935). 
This emphasis on the legitimacy of good faith business judgment underscores the primary commercial function of open-term contracts. The buyer accepts a requirements contract because it msures production flexibility. That objective encompasses the possibility that in periods of decreasing profits, requirements will be reduced. ${ }^{72}$ The requirements arrangement is regarded as one tool which can be utilized to assist the profitability of a buyer's busmess; it has a flexibility which insures that supply levels will be directly responsive to business judgments about supply needs. If the buyer were bound to prior performance level, his requirements contract would hardly be a useful tool in profit maximization. Indeed, it would be a major impediment to that objective in periods of business contraction: the buyer would be bound to accept goods which he neither needed nor could profitably use.

In short, the prior cases recognized what surely must be a universal truth: a party is not likely to bargain away his right to run his business according to his best judgment. Indeed, it is likely that any significant limitation upon business judgment as it relates to profit maximization will receive attention in the terms of the contract of the parties. Seemingly these propositions are sufficiently basic that they should be reflected in the language of the Code.

The Code language. The primary support for good faith as the singular standard against which reduced requirements are to be judged is found in the Comment to section 2-306. There is, however, reason to pause with the language of the text itself. The word forms used are, to say the least, curious, and they reflect, at best, a drafting intent which is suggestive in its ambiguity. Particularly relevant are the verbs used in the exception proviso. That provision sets down the rule that no unreasonably disproportionate quantity may be "tendered or deinanded." Where a drastic reduction in the buyer's requirements occurs, there is no unreasonably disproportionate tender, for that term describes only a seller's act, a performance not in question in the instant situation. ${ }^{73}$ But is a disproportionate quantity being

72. See Ft. Wayne Corrugated Paper Co. v. Anchor Hocking Glass Corp., 130 F.2d 471 (3d Cir. 1942); William C. Atwater \& Co. v. Terminal Coal Corp., 115 F.2d 887, 888 (1st Cir. 1940) (sale of requirements buyer's business "made in absolute good faith and for the purpose of preventing further financial losses .... in a losing business").

73. A construction which would make the exception proviso applicable to the seller's tender in the situation where the requirements of the buyer have declined is suggested in 102 U. PA. L. REv. 654, 664. The argument is that, by applying the word "tender" to a requirements seller in a case where the buyer's good faith requirements decline an unreasonably disproportionate amount, the seller may force the 
"demanded"? Arguably not, if that term is given its connotative meaning as suggesting a bold or forceful assertion. It has been contended, therefore, that the term "demanded" has no applicability to the buyer's conduct in the situation where he is attempting to reduce his level of consumption and avoid the seller's efforts to proffer quantities he does not need. ${ }^{74}$ The term does, however, accurately describe the quality of the buyer's order where his requirements have significantly increased and he looks to the seller to increase his supply accordingly. The buyer's approach in such a case is one of exacting a performance which the seller, because of limited production capacity or whatever, may be either unable or unwilling to undertake. An expanded level of performance is "demanded."

In the final analysis, not many will be persuaded to support the

buyer to take up to a reasonable variation. "This would seem to be the interpretation intended by Comment 3 which states that 'an agreed estimate is to be regarded as a center around which the parties intend the variation to occur." IId. The author points out, however, that such a construction appears to be inconsistent with the assertion in Comment 2 that good faith discontinuance is possible. Id.

74. See id. at 664. Cf. Duesenberg \& King $\$ 4.05[2]$.

75. Popular dictionary analysis attributes a special meaning to the term when it is used in a legal context. In its noun form, it may mean a requisition or a legal claim. The Random House Dictionary of the English Language 383 (unabridged ed. 1967). See Webster's Third New INT'L Dictionary 598 (1961). Thus, the Code language may describe only the buyer's act of exercising what he views as his contractual right to order only such goods as he requires. The difficulty with this view is that it strains even the accepted legal variation of "demand" and gives a meaning to scction 2-306 which is not apparent upon the face of that provision. "Deinand," as used in the law, often describes the specialized act of making a formal request in order to satisfy the precondition of more substantive rights and remedies. Thus, a "demand" for payment must precede suit on an instrument. In a more general sense, the term may imply that one's request carries the force of law and that compliance is the only acceptable response. Neither of these legal usages properly describes the buyer's act in attempting to deviate from prior performance levels. In this posture, the buyor must assume a less affirmative stance.

It might also be argued that the term "disproportionate" can apply to either an increase or decrease in the buyer's requirements, since the term speaks only to the question of relative size and, thus, may include a variation either upward or downward. Had the exception been intended to apply only where requirements increased, the argument would proceed, that limitation would have been expressed in a more precise phrase and the section might have read: "no quantity disproportionately in excess of ..." or "no quantity unreasonably in excess of prior requirements may be demanded." By way of rebuttal, it must be noted that with regard to requirements contracts, the crucial term is "demanded." While the phraso "disproportionate" admits of either upward or downward fluctuation, only a greater quantity would be "demanded" in the sense seemingly intended in section 2-306(1). Thus, the quantity description-"unreasonably disproportionate"-gains its substance from the word chosen to describe the requirements buyer's act and the drafters cannot be said to have used phrasing which indicates an intention to include disproportionately smaller orders within the statutory exception. 
singular good faith standard solely on the basis of the above construction of the word "demnanded." "78 The argument is not, however, without some attraction. But standing alone, it partakes of too great a subtlety; it is not the sort of distinction upon which great legal principles are laid, whether intended or not. Many will feel that had the drafters intended such subtlety, either the text of the Code would have been made more clear or the Comment would have included an explicit explanation. ${ }^{77}$ But it does not require much close work with the Code to realize that caution and crystal clarity were not uniformly applied as drafting guidelines in preparation of the model statute. Few Code arguments will be won on the basis of what was not stated or made clear. The great virtue of the Code-that it received the attention of a great many minds-has also to some extent frustrated its goal of uniformity, at least in the sense uniformity of construction is aided by uniformity in draftmanship.

While it can be conceded that the Comment does not make explicit the intended meaning of the verb "demanded" as used in the exception proviso, the Comment and its history do suggest application of the singular good faith test in the reduced requirements context and, thus, inferentially lend some support to the limiting definition of the term suggested above. This is shown below. The extent to which the suggested construction is rehed on for support can be briefly stated. In sum, it is felt that the drafters' choice of a word which carries value-connotations applicable only where the requirements buyer's demands increase does hittle more than create an ambiguity. It is not contended that the word choice should carry the argument for the singular good faith standard. Rather, the term provides the invitation for one to search into the Comment language as well as to formulate

76. Perhaps the connotative sense of "demand" was not intended. The term "demand" has a meaning in economic analysis which suggests only a desire to purchase. This usage conveys no value-assuming connotation with respect to the vigor of the requests of the consumer. Thus, a requirements buyer would be said to have demands, whatever his new level of consumption relative to prior needs. It is doubtful, however, that the term "demanded" in section 2-306 has reference to the phrase of the economist, since in a statute of general application, it is unlikely that the drafters would borrow a term from a discipline not generally within the competence of those who would deal with the enactment.

77. But a contrary argument could also be suggested: other more neutral terms such as "ordered" or "requested" were available; since these were not chosen, a negative inference is therefore warranted. It might further be suggested that despite the limited validity of drawing inferences from the drafters' failure to choose alternative phrasing, that analysis may have more respectability with relation to the Code than in other statutory treatments, if only because of the extensive scrutiny given the Code by its formulators, supporters, and critics. These arguments suffer the same deficiency as that mentioned in the text. 
a construction of the Code text from the principles which seemed to be operative in pre-Code cases.

The drafters' commentary. The view that decreases in requirements are limited by a standard other than good faith gains some support from the drafters' Comment. Comment 3 provides:

If an estimate of output or requirements is included in the agreement, no quantity unreasonably disproportionate to it may be tendered or demanded. Any minimum or inaximum set by the agreement shows a clear limit on the intended elasticity. In similar fashion, the agreed estimate is to be regarded as a center around which the parties intend the variation to occur.

The paragraph is, of course, directed to the situation in which the parties have included a specific perforinance estimate in their agreement. Yet, the paragraph apparently was also intended to enlighten Code readers where there is only a prior requirements level and no contract estimate, for the language of the Code equates the two criteria: "except that no quantity unreasonably disproportionate to an estimate or in the absence of a stated estimate, to any normal prior . . . requirements . . .."Thus, whatever is said about variations from estimates would arguably apply to variations from prior performance levels as well. While an argument might be made that estimates should have a greater controlling effect on the parties' performance under the contract, this proposition has been considered, and generally rejected, in pre-Code decisions. ${ }^{78}$

78. There may be strong policy reasons for giving great weight to the fact that the parties bargained about an expected level of performance. The presence of the estimate may mean that their reasonable expectations are more definite than in the situation where only a prior performance level is involved. See, e.g., Merriam v. United States, 107 U.S. 437 (1883); Knowles Foundry \& Machine Co. v. National Plate Glass Co., 274 Ill App. 570, 577-80 (1934); C.A. Andrews Coal Co. v. Board of Directors, 151 La. 695, 92 So. 303 (1922); Duesenberg \& Kino \& 4.05[2], at 4-56. On the other hand, the fact that the quantity figure is merely an estimateand not a firm amount-is strong evidence that the parties were unable or unwilling to define precisely the extent of the commitment. Courts have been quite receptive to the view that the indefiniteness of the estimate suggests that the parties did not intend to be bound by it. The leading case in this regard is Brawley v. United Statcs, 96 U.S. 168 (1877); the most recent, Romine, Inc. v. Savannah Steel Co., 117 Ga. App. 353, 354, 160 S.E.2d 659, 660-61 (1968). See also Shader Contractors, Inc. v. Umited States, 276 F.2d 15 (Ct. Cl. 1960); M.W. Kellogg Co. v. Standard Steel Fabricating Co., 189 F.2d 629 (10th Cir. 1951); Marx v. American Malting Co., 169 F. 582, 584 (6th Cir. 1909); Wolff v. Wells Fargo \& Co., 115 F. 32, 36 (9th Cir. 1902); Rosenberg Bros. \& Co. v. Beales, 56 Cal. App. 212, 215-16, 205 P. 18, 20 (1922); Bautovitch v. G.S. Lumber Co., 129 La. 857, 859-60, 56 So. 1026, 1027 (1911); Stanfield v. Arnwine, 102 Ore. 289, 296-97, 202 P. 559, 562-63 (1921); Kenan, McKay \& Spier v. Yorkville Cotton Oil Co., 109 S.C. 462, 468-69, 96 S.E. 524, 525-26 (1918); Arcola Sugar Mills Co. v. Farmer Hamlett's Co., 220 S.W. 385, 
The critical Comment language is the last sentence which establishes an estimate of requirements - and, therefore, a prior consumption level -as "a center around which the parties intend the variation to occur." Since the standard is a "center" point and since variations are to occur "around" it, the variation may be either an increase or decrease. In identifying the standard as a median point-rather than a limitation upon upward variations only - the Comment may evidence the drafters' intent to encompass both types of variations within the statutory exception. ${ }^{79}$ If the deviation is a radical increase in demand, the seller incurs no liability for continuing to supply at prior levels. Conversely, and most responsive to our case, a significant downward deviation from the inedian deprives the seller of a portion of his bargain and may obligate the buyer either to continue performance according to prior standards, ${ }^{80}$ or more likely, to pay money damages. ${ }^{81}$

But a more specific reference to the question of the effect of a drastic reduction in the requirements buyer's demand is found in Comment 2. The Comment specifically endorses application of an unconditional good faith standard in this situation. The relevant language is introduced by the general rule that:

The party who will determine quantity is required to operate his plant ... in good faith and according to commercial standards of fair dealing in the trade so that his output or requirements will approximate a reasonably feasible figure.

This is followed by the qualification that "reasonable elasticity is expressly envisaged" by section 2-306. To this point, the language presents no particular insight into the problein of a drastic reduction in

387 (Tex. Civ. App. 1920); Gulf Ref. Co. v. Brown-Lloyd Co., 167 S.W. 162, 164 (Tex. Civ. App. 1914); Loeb v. Winsboro Cotton Oil Co., 93 S.W. 515, 515-16 (Tex. Civ. App. 1906); Mathieson Alkali Works v. Virginia Banner Coal Corp., 147 Va. 125, 137-40, 136 S.E. 673, 677 (1927); Excelsior Wrapper Co. v. Messinger, 116 Wis. 549, 93 N.W. 459 (1903). See generally 28 CoLUM. L. REv. 223, 228-30.

The Code language does not endorse any distinction between estimates and prior requirements. Ascribing due priority to the statutory language compels the equation of the two standards despite the invitation to limit Comment 3 to cases involving estimates. It is clear, however, that the parties nay, by agreement, establish an estimate which limits the freedoin of the quantity-determining party to vary from it. Harry Thuressou, Inc. v. United States, 453 F.2d 1278, 1280-82 (Ct. Cl. 1972).

79. Some of the secondary material supporting the two-prong approach suggests this view. See, e.g., Duesenberg \& KING $\$ 4.05[2]$; R. Nordstrom, supra note $6, \S 40$.

80. Brief mention is made of equitable remedies, including specific performance, in the context of requirements contracts in Note, supra note 10, at 1229 . See also Mantell v. International Plastic Harmorica Corp., 141 N.J. Eq. 379, 390-94, 55 A.2d 250, 257-59 (Ct. Err. \& App. 1947); Central Power \& Light Co. v. Purvis, 67 S.W.2d 1086, 1095 (Tex. Civ. App. 1934).

81. See generally 5 A. CoRBIN, Conrracts $\$ \$ 990-1075$ (1964). 
requirements undertaken in good faith. But the next clause of the Comment seems directly responsive to this situation: "good faith variations froin prior requirements are permitted even when the variation may be such as to result in discontinuance" (emphasis added).

To illustrate the intended impact of this language, the Comment suggests that "a shutdown by a requirements buyer for lack of orders may be permissible ...."This discussion of the impact of the Code is concluded with a citation to Southwest Natural Gas. ${ }^{82}$ The drafters view the variation there as one "of an extreme sort," but nonetheless deem it a "reasonable variation," suggesting Code approval of the result.

The explicit endorsement of reductions in requirements is qualified only by the reference to good faith. No limitation on the relative size of the decrease is suggested and the possible application of any such standard is negated by the specific mention of reductions which result in discontinuance. Nor does it appear that a special exception was intended for discontinuances which would not apply to any drastic reduction which fell short of complete cessation of demand. Rather, the Comment language suggests that good faith sanctions a continuum of variations between prior requirements and discontinuance. ${ }^{83}$

By contrast, the discussion in Comment 2 with respect to increases in requirements implies that elements other than good faith limit demands by the requirements buyer for increased supplies. The Comment flatly states that ". . . a sudden expansion of the plant by which requirements are to be measured would not be mcluded within the scope of . . . this section ...." Although "sudden expansion" could

82. See text accompanying notes 61-67 supra.

83. See Note, supra note 10 , at 1220 . Pre-Code cases have rejected the notion that a distinction should be made between a mere reduction im quantities and a discontinuance of operations. For example, in Helena Light \& Ry. v. Northern Pac. Ry., 57 Mont. 93, 186 P. 702 (1920), the buyer agreed to purchase such electric power as he required at specified locations. When the buyer abandoned those facilities, the seller argued that the contract should be read to require that some power be consumed. The court dismissed as fallacious the argument that "abandonment of the [facility] constituted a breach of the contract, but the maintenance of a 1-watt electric light there would not." Id. at 105,186 P. at 705 .

84. This clause is then qualified by the statement that "normal expansion undertaken in good faith would be within the scope of this section." UCC $\$ 2-306$, Comment 2 (May, 1949 draft). The intended contrast is presumably between "normal" and "sudden" expansion, but the significance of this contrast is not apparent. The meaning of the phrase "normal" must be interpreted in light of the Code criteria, and, thus, any such expansion must not produce disproportionate demand. See text accompanying notes 97-113 infra. This analysis, although logically compelled, renders the clause conclusory and of limited significance as an interpretive guide. 
presumably occur in good faith, the Comment nonetheless construes section 2-306 as a limitation in this situation, which finds justification in the phrasing einployed in the exception proviso.

The history of the Comment. Even if it can be assumed that Comment 2 unequivocally endorses the good faith standard as the sole limitation upon drastic decreases in requirements, there is an apparent conflict with the principle implied in Comment 3. The latter paragraph states that any estimate, and by implication a prior performance level, serves to peg the quantity terin; any variation from that level, either upwards or downwards, must not be quantitatively significant. The history of the Comment offers some insight into the intended significance of the two paragraphs. The present form of Comment 3 is unchanged from the first publication of the integrated Code in 1949.85 Comment 2, on the other liand, was substantially revised subsequent to the 1949 draft. In its original form, it included only one sentence dealing with variations in output or requirements. It read: "Discontinuance or sudden expansion of either output or requirements must be in good faith in order to avoid liability under the contract." followed by an unqualified citation to Southwest Natural Gas. In the $1950 \mathrm{draft}^{87}$ the paragraph was expanded to include substantially the same elaboration which is found in the present version of the Code:

Reasonable elasticity in the requirements is expressly envisaged by this section and good faith variations from prior requirements are permitted even when the variation may be such as to result in discontinuance. A shutdown by a requirements buyer for lack of orders might be permissible when a shutdown merely to curtail losses would not. The essential test is whether the party is acting in good faith. Similarly, a sudden expansion of the plant by which requirements are to be measured would not be included within the scope of the contract as made but normal expansion undertaken in good faith would be within the scope of this section. One of the factors in an expansion situation would be whether the market price had risen greatly in a case in which the requirements contract contained a fixed price. Reasonable variation of an extreme sort is exemplified in Southwest Natural Gas Co. v. Oklahoma Portland Cement Co. . . .

It shonld be einphasized that it was in the process of this revision that the Comment was amended to state that "good faith variations from prior requirements are permitted even when the variation may be

85. UCC \$ 2-306, Comment 3 (May, 1949 draft).

86. Id. at Comment 2.

87. UCC $\$ 2-306$, Comment 2 (Spring, $1950 \mathrm{draft}$ ). 
such as to result in discontinuance" and to identify Southwest Natural Gas as a case exemplifying an extreme variation which was nonetheless sanctioned under section 2-306. The 1950 revision represents an attempt to deal specifically with the application of the section in the context of decreasing requirements. It was apparently felt that the original version did not provide a sufficient answer for the question of the application of the section in this situation. Because the revision was intended as a clarification, it may be regarded as nore directly responsive to the anticipated questions in this regard than the imterpretation found in Comment 3. While the contrary implication of the third paragraph was not specifically dispelled, the revisor may well have seen no need for modification of that paragraph in light of the explicit statement in the revised Comment 2 that substantial reduction even to the point of discontinuance is sanctioned by the section if undertaken in good faith. The least that can be said is that Comments 2 and 3 are not on equal footing as far as offering guidance for the Code's applicability to the particular problem of diminished requirements. The former represents the drafters' efforts to confront the situation directly while the latter has application only by inference. In this posture, there should be little question as to the drafters' intent.

There may be some question whether modification of the language used in the Comment provides a reliable basis for discerning the intended impact of the section. Indeed, the Code text at one time seemed to suggest that such analysis was not only not to be favored, but also to be avoided entirely. Section 1-102(3)(g) of the 1952 edition of the Code provided that "[p]rior drafts of text and comments may not be used to ascertain legislative intent."88 The Comment to that section suggested the reason for the provision: "Frequently matters have been omitted as being implicit without statement and language lias been changed or added solely for clarity. The only safe guide to intent lies in the final text and comments." 89 This provision was deleted froin subsequent drafts with an accompanying explanation which is not totally satisfactory. ${ }^{00}$

88. UCC § 1-102(3)(g) (1952 draft).

89. $1 d$. at Comment 2.

90. 1956 RECOMMENDATIONS OF THE EDITORIAL BOARD FOR THE UNIFORM COMMER. CIAL CODE 3 explains that "paragraph (3) $(\mathrm{g})$ was deleted because the changes from the text enacted in Pennsylvania in 1953 are clearly legitimate legislative history."

This explanation raises a number of questions: Does it suggest that changes made prior to the 1952 edition adopted in Pennsylvania are not legitimate legislative history? Indeed, should changes made by a group unconnected with the lcgislature 
Quite apart from this vacillation by the drafters, there should be little question that modifications in the text and comments can support guarded inferences about the intended effect of Code language. The Comment to the now-abandoned section 1-102(3)(g) suggests such a result, despite its efforts to the contrary. Text and Comments have occasionally been modified "for clarity." When such a clarifying amendment can reasonably be identified as such, one may infer that the clarification controls over other language which inferentially suggests the contrary or at least leaves the meaning in doubt. This, of course, is the approach used above in construing section 2-306(1): Comment 3 appeared in the original; the crucial language of Comment 2 was subsequently added; even if added "solely for clarity," it tells us something both about what was previously unclear and about what meaning the addition was imtended to convey.

The admomition against use of prior drafts was properly deleted as simply being too rigid. The explanation accompanying the deletion, while otherwise unsatisfactory, recognizes this. ${ }^{91}$ An accepted mode of construction is discarded if comparison of prior drafts is absolutely prohibited. No sound reason suggests that such a prohibition should be universally applied. A more palatable rule is, of course, the one usually followed in analogous situations: inferences inust not be drawn lightly from deletions from or additions to prior drafts; such modifications may have been motivated by factors other than those which first appear. ${ }^{92}$ In the present situation, this suggests that sole reliance should not be placed on the addition of clarifying language to the Comment accompanying section 2-306. This directive presents no great difficulty. The interpretation suggested here gains support from other sources: the specific language used in the clarification, a plausible interpretation of the language of the Code text, ${ }^{93}$ and an analysis of the implications of policy identified in prior law.

be considered legislative history? See A. FARNSWORTH \& J. HONNOLD, supra note 17, at 8 .

91. 1956 RECOMMENDATIONS OF THE EDITORIAL BOARD FOR THE UNIFORM COMMRRCIAL CODE 3. The explanation recognized that when Pennsylvania modified some sections in adopting the Code, it seemed reasonable to allow the inference of "intent" to be drawn from that fact.

92. Cf. United States v. St. Paul, Minneapolis \& Manitoba Ry., 247 U.S. 310 (1918); United States v. Limehouse, 58 F.2d 395 (E.D.S.C. 1931), rev'd on other grounds, 285 U.S. 424 (1932); Bowles v. Goebel, 58 F. Supp. 686 (D.N.D.), aff'd, 151 F.2d 671 (8th Cir. 1945); D.N. Kelley \& Son, Inc. v. Selectmen, 294 Mass. 570, 3 N.E.2d 241 (1936); State ex rel. Taylor v. Hall, 129 Neb. 669, 262 N.W. 835 (1935). See generally 82 CJ.S. Statutes \& 355 (1953).

93. See text accompanying notes 73-76 supra. 


\section{Decreases in Output}

Neither the Code text nor the Comment provides a means for separately analyzing the treatment of decreases in the output seller's product. When output contracts are mentioned, it is in conjunction with requirements contracts. In absence of more particularized expressions of intent, it should be clear that the drafters equated the two types of agreements. Thus, what has been said about the intended impact of section 2-306 upon decreases in requirements should have application to decreases in output, even though the support to be drawn from the text and Comments is not as detailed. ${ }^{94}$ On this basis, decreases in output would be judged against the singular good faith test.

Courts and commentators have accepted the equation of requirements and output contracts. An interchange of precedent between these two forms has occurred even though the priority of functions in typical transactions of each is likely to differ. ${ }^{95}$ The decisions permitting good faith decreases in requirements are mirrored in opinions treating output reductions, although the lesser number of cases dealing with output contracts and the occasional decision to the contrary preclude cer-

94. The Comment to section 2-306 includes several statements which indicate that the drafters assumed that the enforcement and interpretation of output and requirements would be governed by the same principles. For example, it is stated that "a contract for output or requireinents is not too indefimite ...." Comment 2. Similarly, "[i]f an estimate of output or requirements is included in the agreement, no quantity unreasonably disproportionate to it may be tendered or deinanded." Comment 3.

There is one language usage in the text of the section which is susceptible to an interpretation which would provide greater restriction for output fluctuations. The Code uses the terms tendered and demanded, the former presumably referring to output contracts and the latter to requirements contracts. It has been suggested above that the term demanded may refer only to demands for increases in requirements. See text accompanying notes 74-75 supra. This view is premised on the notion that the term carries a connotation indicating the requirements buyer's desire for increased quantities. It will be noted that the term tendered is more clearly neutral in this regard and does not admit of a suggestion of whether the output seller's tender is more or less than his previous tenders. This might suggest that both increases and decreases in output are controlled, while only increases in requirements are limited by estimates or prior output. However, further analysis should suggest that such a reading was not intended. The general equation of the principles governing output and requirements contracts in the Comment, as well as a consideration of relevant policy, support this view. See text accompanying notes 97-113 infra.

95. The requirements buyer typically places greatest emphasis upon the fact that an open-quantity contract affords him an opportunity to adjust his consumption to the deinands of his business. The output seller, on the other hand, will typically be attracted to an output arrangement primarily because of the cost-savings which result from a guaranteed inarket. In each type of contract, however, other motives may well be present. See text accompanying notes 18-35 supra. 
tainty in this judgment. An important aspect of the transfer of precedent is the recognition that the output seller, like the requirements buyer, is not likely to subordinate his business judgment to the potential advantages of his output contract, at least not in the absence of contract provisions which make that choice clear. Thus, courts deciding cases involving decreased output refer to decisions involving requirements contracts for the proposition that the output seller retains, within the bounds of good faith, control of the busmess decisions which affect his level of production. ${ }^{96}$ In short, it is suggested that the same analytical considerations which support the contention that section 2-306 requires apphication of only the "good-faith" standard to cases mvolving reduced requirements apply with parallel force and effect to instances of decreased output.

\section{Increases in Requirements and Output}

It is apparent that the Code was intended to limit some types of quantity variation by a standard other than the good faith criteria. As there is a basis for substantial doubt that the coverage either should or was intended to be extended to decreases in requirements or output, it may be reasonable to posit that increases in either could not be "unreasonably disproportionate to any stated estimate or in the absence of a stated estimate to any normal or otherwise comparable prior output or requirement . . .."97 Such a result would limit the utility of openquantity contracts, for the ability to respond to changes in profitability would not extend to opportunities for substantially larger profits. Nonetheless, imposition of a limitation on increases in requirements and output can be defended as eliminating a potentially ruinous advantage in the quantity-determining party, while at the saine time preserving his control over the essential busmess judgnients of his operation.

Prior law. An early case which had a significant role in shaping the judicial attitude toward disproportionate increases in quantity was Eustis Mining Co. v. Beer, Sonheimer \& Co. ${ }^{98}$ The buyer had agreed

96. See, e.g., Neofotistos v. Harvard Brewing Co., 341 Mass. 684, 688, 171 N.E.2d 865,868 (1961). The court held that in the output contract under consideration, "[i]t was necessarily contemplated by the parties that, whatever the [level of] production, it would be governed by business conditions." Id. Support for this conclusion was found in Royal Paper Box Co. v. E.R. Apt Shoe Co., 290 Mass. 207, 195 N.E. 96 (1935). See also Keener Oil \& Gas Co. v. Consohdated Gas Util. Corp., 190 F.2d 985, 990 (10th Cir. 1951).

97. UCC \& 2-306.

98. 239 F. 976 (S.D.N.Y. 1917). 
to purchase the entire cinder output of the seller's plant. The cinders were a by-product of sulphur refining, the seller's main business. The advent of World War I during the term of the contract significantly increased the demand for sulphur. In responding to this new demand, the seller produced cinders at a rate which exceeded prior levels of production by two-thirds. The federal district court held that the buyer was bound to accept the increased output. In his opinion, an unsympathetic Learned Hand suggested a rationale which was resounding in its dispassion:

I agree that the production occasioned by the Great War was a surprise to both sides, and that it was not within their forecast of the future. It is altogether likely that the defendant would have cried off upon the whole bargain, had they thought it probable. Contracts cannot, however, be treated so loosely: if the parties wish more certainty, they must use more certain words. ${ }^{99}$

This general approach has been followed in other cases, although often upon facts which suggest that the approval of increased quantities is more likely the result of a judicial decision to bind the parties to a foreseeable event than of wholehearted endorsement of the Eustis rationale. ${ }^{100}$

Despite these precedents, there are indications of judicial concern for the potentially harsh consequences of sanctioning unlimited increases in the consumption of the requirements buyer or the production of the output seller. Evidence of this concern can, for example, be seen in the treatment of jobbers who held requirements contracts. Even after courts had dispelled nost of their doubts about the mutuality of open-quantity contracts, a distinction was made between contracts entered into by requirements buyers who had an established manufacturing operation and those who were nere jobbers or dealers. ${ }^{101}$ The reluctance to find inutuality, although now apparently quieted by the Code, ${ }^{102}$ lingered much longer with respect to the latter.

99. Id. at 986.

100. See, e.g., Marx v. American Malting Co., 169 F. 582 (6th Cir. 1909); E.G. Dailey Co. v. Clark Can Co., 128 Mich. 591, 87 N.W. 761 (1901). In both cases, the court emphasized that the increased needs of the buyer/plaintiff were foreseeable by the parties on the basis of facts known at the time the requirements contracts were entered into. See also Havighurst \& Berman 7 n.27.

101. See, e.g., Crane v. C. Crane \& Co., 105 F. 869 (7th Cir. 1901); Nassau Supply Co. v. Ice Service Co., 252 N.Y. 277, 169 N.E. 383 (Ct. App. 1929); Oscar Schlegel Mfg. Co. v. Peter Cooper's Glue Factory, 231 N.Y. 459, 132 N.E. 148 (1921).

102. UCC $\$ 2-306$, Comment 1 states that subsection (1), specifying the measure which defines the parties' obligations under open-quantity contracts, "applies to such contracts of non-producing establishments such as dealers or distributors as well as to manufacturing concerns." See also note 44 supra and accompanying text. But see 
One of the policies underlying the stricter scrutiny of jobbers' contracts was concern for the extreme ease with which the jobber could escalate his consumption level under a requirements contract. Indeed, merely by reducing the price at which he resold an item, the jobber could significantly increase his requirements and substantially aggravate the burden of the requirements seller. And with the same ease, the jobber could reduce his requirements by limiting his promotional efforts or raising his profit margin, perhaps after his seller had expanded his plant or otherwise relied to his detriment in response to prior requirements levels. While there were certainly situations which could disprove the rule, the established manufacturer was less likely to have a capacity for such ready response to market fluctuations. Before his consumption level could imcrease drastically, he would need to make capital investments for equipment and facilities expansion. Once made, these were likely not to be readily withdrawn. In short, courts may have been reluctant to enforce jobber-requirements contracts because of a desire to shield the requirements seller from an abnormal increase in his legal obligation. ${ }^{103}$ Implicit in this reluctance is the assumption that it would be unfair for one party to a requirements contract to suddenly and substantially increase the burden of the other.

There are other indications that significantly disproportionate quantity increases were not favored. This attitude is reflected in damage awards to the quantity-determining party which were limited to the amount which arises from, normal operation of the business rather than an amount which reflects substantial operational changes. ${ }^{104}$

Comment, supra note 44 , at 684 , where it is suggested that since the Uniform Commercial Code itself does not elimmate the need for mutuality in requirements contracts, the possibility remains for a court to use pre-Code judge-made law to invalidate a requirements contract on lack-of-mutuality grounds. See also DUESENBERG \& KING $\S 4.05[1]$, at $4-48$ to $4-52$.

103. See, e.g., Crane v. C. Crane \& Co., 105 F. 869, 872 (7th Cir. 1901), where the court evidences its concern that the spiral effect of a favorable contract price negotiated by the jobber at the time the contract was entered into might place an unreasonable economic burden upon the seller. That is, the better the contract price is in relation to the current market price, the more the jobber will order and sell; and the more the jobber can sell, the more competitive he can be; thus, the mnore he will order. The Crane reasoning was cited with approval in Colien v, Clayton Coal Co., 281 P. 111, 114 (Sup. Ct. Cal. 1929). See also Oscar Schlegel Mfg. Co. v. Peter Cooper's Glue Factory, 231 N.Y. 459, 132 N.E. 148 (1921). In Schlegel the court was concerned that a more than 200 percent increase in the market price of the glue that was the subject of the requirements contract had stimulated the jobber to so increase his orders for glue at the lower contract price that a great economic injustice was visited upon the seller.

104. See Fayette-Kanawha Coal Co. v. Lake \& Export Coal Corp., 91 W. Va. 132, 112 S.E. 222 (1922). 
Other courts avoid the Eustis rationale altogether and interpret the contract so as to limit the obligation imposed to that which would have been suggested by the conditions which existed at the time of the making of the agreement. ${ }^{105}$ Finally, at least one commentator early identified a judicial tendency toward disapproval of an imcrease in buyer's orders in situations where a likely cause of the increase was the fact that the contracts price was substantially below the inarket price, thus enhancing the buyer's competitive position at the expense of the seller. ${ }^{100}$

Policy support for limiting quantity increases. If it is assumed that an important commercial function of an open-quantity contract is to afford one party an opportunity to control the rate of production in his operation, it might seem that he should be permitted to rely on the contract to improve the profitability of his business. The Code clearly does not attempt to preclude all business expansion. Indeed, Comment 2 is emphatic in its endorsement of "normal" expansion. Doubt is expressed, however, as to whether "sudden" expansion would be permitted. ${ }^{107}$ While this distinction is not particularly instructive, it does suggest that there may be policy reasons for limiting the quantitydetermining party's right to increase the quantity consumed or produced.

To be sure, such limitation would detract from the utility of the open-quantity agreement for the party who desires to utilize the contract for ultimate profit maximization, at least to the extent of requiring more attentive draftsmanship. ${ }^{108}$ But a legitimate purpose of the law of commercial transactions is to teinper one party's attempt to secure his greatest advantage with concern for the potential impact upon the party froin whoin performance can be exacted. If unbridled expectations are likely to produce considerable economic hardship for one

105. See C.A. Andrews Coal Co. v. Board of Directors of Public Schools, $151 \mathrm{La}$. 695, 92 So. 303 (1922); Smith v. Donk Bros. Coal \& Coke Co., 260 S.W. 545 (Mo. Ct. App. 1924). Cf. Asahel Wheeler Co. v. Mandelson, 180 App. Div. 9, 167 N.Y.S. 435 (1917); Moore v. American Molasses Co., 106 Misc. 263, 174 N.Y.S. 440 (1919).

106. See Havighurst \& Berman 6 n.20.

107. The specific language in Comment 2 is as follows: "[A] sudden expansion of the plant by which requirements are to be measured would not be included within the scope of the contract as made but normal expansion undertaken in good faith would be within the scope of this section." See note 84 supra.

108. Section $2-306$ is supplementary rather than mandatory, see UCC $\S 1-102(3)$, and the quantity-determining party may "draft" his way out of the rigidity of the Code. For example, a term setting a large maximum quantity limit on quantity may be used to alert the other party to the probability of a substantial quantity increase during the contract period. In addition, specific language may be used to give the requirements buyer or output seller the right to raise the quantity in excess of norinal amounts. 
party, the stability of commercial transactions is promoted by a limitation upon the effect of a potentially oppressive contractual term. An oppressive feature is likely to produce litigation on a wide scale, which in turn accentuates the lack of definition in the rights secured by a particular commercial form; resort to a limitation restores definition. Several reasons support the imposition of a limitation upon quantity increases under open-quantity agreements.

1. Potential for undue advantage. An obvious objection to permitting drastic and relatively sudden increases in quantity is that such a change is not likely to be anticipated by the party required to supply requirements or purchase output. This element of surprise, in itself, perhaps suggests the desirability of imposing a quantity limitation, for development of complex economies is, to a significant degree, dependent upon the stability of commercial relationships. But ultimately there nnust be inquiry into the risks which each party has assumed to determine whether the unanticipated detriment is one against which generalized protection should be afforded..$^{109}$

It can be suggested, of course, that decreases in quantity may be attended by an element of surprise. But the consequences of that sort of unanticipated quantity change are less likely to suggest overreaching or to produce an inequitable distribution of risk than is true where the variation is an increase in output or requirements. To permit unanticipated disproportionate increases in quantity is to allow one party to profit at the expense of the other. The quantity-determining party realizes the benefit of the open-quantity contract, but only by imposing a potentially onerous burden on the promisee. The output buyer, for exainple, may be compelled to accept goods which he inay neither need nor be able to use-or pay the equivalent in damages. Likewise, in order to supply the requirements buyer with his new level of de1nand-and afford him the opportunity to profit by his contract-the requirements seller must either produce his product in significantly greater quantities, incurring the expense of gearing up for increased production, or divert the goods from other markets, suffering the possible loss of goodwill and other detriments. The potential severity of the impact of an unanticipated disproportionate increase may provide a sufficient basis to question whether, as a inatter of policy, it should be permitted. The harshness of the result is not only likely to produce litigation, but also will make strong demands upon the equitable sensi-

109. Cf. Marx v. American Malting Co., 169 F. 582 (6th Cir. 1909); E.G. Dailey Co. v. Clark Can Co., 128 Mich. 591, 87 N.W. 761 (1901). 
tivities of a court, a feature which portends an inconsistency of decision potentially destructive of the stability of commercial undertakings in this area.

In contrast, unanticipated disproportionate decreases in quantity do not present the same conflict. Rather than raising the possibility that one party will profit at the expense of the other, a significant decrease inore often poses the policy question of whether the particular risk-a inarket contraction or similar business risk-will be spread between the two parties or will be left solely with the quantity-determining party. Neither party will "profit."110 Permitting the decrease will diffuse the risk and seemingly lessen its total economic impact. This result is particularly persuasive where inarket reversals proinpt the decrease. The quantity-determining party suffers from the condition because he inust accept lower profits. The promisee is also affected, for his profits will contract upon the loss of a source of demand, if he is a requirements seller, or of supply, if he is an output buyer. Of course, soine situations in which quantities are decreased cannot be viewed as involving an equitable distribution of the consequence of adverse economic conditions. For example, the requirements buyer may have eliminated or reduced his orders not as a result of a general business decline but simply because he found a less expensive substitute product. Such situations are not immune from judicial scrutiny and the overriding requirement of good faith should serve as an adequate basis for control. ${ }^{111}$

110. See 102 U. PA. L. Rev. 654, 665. See also Havighurst \& Berman 15.

111. The Southwest Natural Gas case provides an excellent illustration of the role which good faith can play in cases in which quantity reduction results from the requirements buyer's substitution of a less expensive product. See 102 F.2d 630 (10th Cir. 1939). On the surface, the case might appear to be one in which the buyer was attempting to use the open-quantity contract to impose a hardship on the seller. After purchasing a substantial amount of natural gas from Southwest for a number of years, the buyer converted to a new source of heat and suddenly reduced his orders to less than twenty percent of prior orders. The seller could complain that in this attempt by the buyer to increase the profitability of his operation, it was he, the seller, who was made to bear the entire economic burden, and that in no sense were buyer and seller "sharing" the adverse economic consequences. The court correctly looked to the good faith standard to evaluate the seller's position. Despite the consequence for the seller of the buyer's substitution, the facts of the case did not suggest that this was a situation in which the buyer had arbitrarily undercut the seller's expectations in the pursuit of greater profits. The term of the contract was longer than the anticipated useful life of the buyer's equipment. Hence, it was reasonable for the parties to assume that in purchasing replaceinent equipment, the buyer would take advantage of technological innovations, such as that which permitted him to utilize a less expensive heat source. Thus, the court could find that the buyer had satisfied his obligation of good faith. Had a substitution been made shortly after the contract was entered into or merely 
The point of this analysis is only to suggest that where the quantity-determining party's good faith has been established, sanctioning abnormal decreases in quantity achieves the salutary result of diffusing business and market risks, while permitting unusual increases in quantity presents a less defensible potential for one party's profiting to the extreme detriment of the other. In this sense, then, quantity increases present a potential for undue advantage not present in other types of variations.

2. Absence of a natural limitation on fluctuations. As discussed above, the risk of decreases in quantity is limited by the presence in the quantity-determining party of a desire for profit maximization. This feature provides an impetus to that party not to reduce his level of business. The desire for profitability will often prompt the party to overcome inarket difficulties rather than pass them on in the form of reduced requirements or output. Thus, the desire for profitabilityteinpered with the requirement of good faith-serves as a natural limitation upon decreases in quantity and, to the extent it is operative, lessens the need for more artificial limitations such as that which some find in section 2-306. ${ }^{112}$

Increases in requirements are not affected by a similar constraint. Indeed, the desire for profit maximization inay have the opposite effect of encouraging constantly larger levels of requirements consumption or output production. Given other favorable conditions, the quantitydetermining party will seek to decrease his marginal unit costs, and hence increase his profits, by increasing the number of umits which he produces. If, for example, the quantity-determining party has unused production potential at the time of contracting, he would be inclined to maximize the return of capital and other resources to the extent that market conditions would permit. Since these pressures for enlargeinent are not naturally suppressed, there may be a need for artificial limitations. At a minimum, the absence of a natural limitation on increases makes this form of variation a more appropriate subject of statutory control.

3. Absence of interference with business judgment. The thesis has been developed that a capacity to decrease quantities, restrained only by the requirement of good faith, is desirable because it preserves

because the market price of other fuels had decreased, the result would undoubtedly have been different. A major attraction of the good faith concept is the capacity which it affords for recognizing these distinctions.

112. See HML Corp. v. General Foods Corp., 365 F.2d 77, 81 (3d Cir. 1966); 28 ColUM. L. REv. 223,224 , n.8. See generally note 54 supra. 
to the quantity-determining party relative freedom to exercise his business judgment in the operation of his facility. It is posited that a party who entered an open-quantity agreement is not likely to have relinquished the right to decrease requirements or output in response to business or market conditions. ${ }^{113}$ Because flexibility in effectuating business judgment is likely to be a fundamental concern of the party who has chosen not to accept a fixed-quantity obligation, a statutory interpretation which significantly inhibits it must be suspect.

Alleviation of the liarsli consequences of an unexpected, abnormal increase in quantity, lowever, need not be subverted to an overriding concern for the preservation of business judgment, for a limitation upon disproportionate increases represents a less disruptive intrusion upon that fundamental precept. A requirements buyer, for example, can continue to operate his business so as to maximize profit even if his requirements seller is not required to meet disproportionately increased needs. The buyer is simply forced to look elsewhere for his supplies. While alternative sources may not be as desirable in terms of price or quality, the buyer is left free to attempt to minimize a disparity through negotiation or substitution. He continues in full control of his business and resources, with the means to overcome the consequences of an artificial limitation on variations under his open-quantity contract.

In the final analysis, the relative absence of impact upon business judgment may not stand alone as a reason for imposing a limitation upon quantity increases. It does suggest, however, the rationality of a rule which differentiates between types of quantity variations; and it does influence the decision to impose a limitation, since that conclusion represents a balancing of the relative impact of the result upon buyer and seller. While decreases in quantity lave potentially liarsh consequences for the requirements seller or output buyer, there can appropriately be a paramount concern for the quantity-determining party's control of his business. Since the concern for intrusions upon business control is not as compelling where quantity increases are involved, the need to alleviate the potential for undue advantage should, in that context, be given greater weight.

\section{CONCLUSION}

A thesis of this discussion is that the interpretation of section 2-306 should be undertaken with proper deference to the principles

113. See text accompanying notes 46-48 supra. See also Note, Business Practices and the Flexibility of Long-Term Contracts, 36 VA. L. REV. 627 (1950). 
which have been developed in the numerous pre-Code decisions involving open-quantity contracts. Any attempt to introduce fundamental rcdirection of those developments must sustam a heavy burden in establishing the defects of the prior trends. Froin all the evidence which appears on the face of the Code, the drafters did not purport to undertake that task. Although the Code text and, more particularly, the Comments are susceptible to an imterpretation which introduces a basic revision of prior law, that result was apparently not intended. Properly read, section 2-306 operates as a codification of both the good faith standard and an equitable limitation on the extent to which quantities can be increased by the quantity-determining party. While the latter feature lad not been fully developed in the common law decisions, this is in large part due to the relatively few cases which presented the issue and does not necessarily reflect a judicial lesitancy to accept the wisdom of that limitation. Indeed, there are indications that the courts were sensitive to the burden which a drastic increase in quantity might impose. ${ }^{114}$

It is feasible to regard the suggested interpretation of the Code as leaving the requirements seller or output buyer vulnerable to overreaching by the quantity-determining party who finds it advantageous to reduce suddenly the level of his consuinption or output. However, that concern fails to take account of the substantial role which the good faith standard can play in the resolution of controversies under section 2-306. Prior to the Code, the good faith criteria provided the basic interpretive tool in cases involving open-quantity contracts. It proved quite adequate as a basis for distinguishing situations in which the quantity-determining party was inerely pursuing a better bargain elsewhere froin those in which a change in needs or output resulted froin the exercise of the business judgment which the quantity-determining party had reserved for himself. It should not be expected that the good faith requirement will play a different, or less significant role under the Code. This article, therefore, has suggested that section 2-306 be read to leave that standard unfettered by a proportional limitation on quantity reductions, the type of variation which appears most frequently in litigation.

In particular situations a party may properly be concerned that the good faith criterion is too indefinite to offer the protection which lie needs. If his acceptance of an open-quantity contract requires a substantial commitment of new capital and other resources, he may

114. See notes $\mathbf{1 0 4}$ and 105 supra and accompanying text, 
desire an assurance that he will have an opportunity to secure a return from his imvestment. The interpretation suggested here does not limit his options in providing that security. It can be expected that the parties will be mindful of the Code's invitation to modify its basic rules by agreement and that alternatives, such as a minimum-maximum quantity-term, will be considered. The function of the Code should only be to provide general rules which will operate when the parties have otherwise not been specific in defiming the contours of their agreement. In attempting to deal with these situations, it is appropriate for the Code to draw heavily on principles which admit of considerable flexibility. With respect to section 2-306, this is achieved by de-emphasizing the role of an objective quantity limitation and re-establishing the predominance of the good faith criteria. 